\title{
Solidarity versus Sisterhood: Women's Issues, Feminism and Potential in Poland
}

\author{
Abigail E. Miller \\ West Virginia University
}

Follow this and additional works at: https://researchrepository.wvu.edu/etd

\section{Recommended Citation}

Miller, Abigail E., "Solidarity versus Sisterhood: Women's Issues, Feminism and Potential in Poland" (2011). Graduate Theses, Dissertations, and Problem Reports. 788.

https://researchrepository.wvu.edu/etd/788

This Thesis is protected by copyright and/or related rights. It has been brought to you by the The Research Repository @ WVU with permission from the rights-holder(s). You are free to use this Thesis in any way that is permitted by the copyright and related rights legislation that applies to your use. For other uses you must obtain permission from the rights-holder(s) directly, unless additional rights are indicated by a Creative Commons license in the record and/ or on the work itself. This Thesis has been accepted for inclusion in WVU Graduate Theses, Dissertations, and Problem Reports collection by an authorized administrator of The Research Repository @ WVU. For more information, please contact researchrepository@mail.wvu.edu. 
Solidarity versus Sisterhood:

Women's Issues, Feminism and Potential in Poland

\author{
Abigail E. Miller \\ Thesis submitted to the \\ Eberly College of Arts and Sciences \\ at West Virginia University \\ in partial fulfillment of the requirements \\ for the degree of \\ Master of Arts \\ in \\ History
}

Robert Blobaum, Ph.D. Elizabeth Fones-Wolf, Ph.D.

Katherine Aaslestad, Ph.D.

Department of History

Morgantown, West Virginia

2011

Keywords: Feminism; Poland; Solidarity; Women; Transition Copyright 2011 Abigail E. Miller 


\author{
ABSTRACT \\ Solidarity and Sisterhood: \\ Women's Issues, Feminism and Potential in Poland
}

Abigail E. Miller

Exploring the history and trajectory of women's issues and activism in Poland, this work begins discussing the early twentieth century, moving through to the time period of the Solidarity trade union movement, continuing through the political transitions during the 1990s and ending in the present day. By examining a multitude of issues which affect women's lives (in the quotidian and overall senses), the existence, development and necessity of women's organizations and feminist activism in Poland becomes apparent. Labor, social, legal, and economic issues are of primary concern in contextualizing Polish women's place in society.

The introductory chapter begins by examining Polish women's early activity in political and economic issues to provide context for their later involvement in Solidarity's operations. The aim of the second chapter is to discuss women's involvement with the Solidarity movement and to recognize the consequences of their subsequent exclusion from political processes during the country's transition from communism to democracy.

Focusing first on the historical context of women in Polish society through the 1990s, this work then proceeds to examine the unique case of what it means to be a woman in Poland by introducing specific issues such as the controversial abortion laws, the influence of the Catholic Church, nationalism and Polish politics in the early transitional period and periodically comparing the Polish case to that of German women. The following chapter then proceeds to examine the vast spectrum of women's activism in Poland and the cultural difficulties in embracing the concept of feminism. Finally, the last chapter of this work details current issues, problems and potential for Polish women and concludes with an analysis of the importance of women's activism and feminist principles of equality in society as critical to national and international measures of progress and development.

The purpose of this work is to note the existing inequality between men and women, which has developed in an interesting manner in Polish society. Given the unique aspects of gender inequality in Poland this work clearly establishes a need for further scholarship and support for women's activism. In a world which some consider post-feminist, the importance of cultivating a sense of feminist curiosity in such research is of utmost importance. Continuing to address the inequality and discrimination propagated by gender stereotypes and cultural tradition is not only a choice, but a duty for historical scholars. In the case of Poland, unique ties between the Catholic Church and Polish nationalism have created a climate in which women's activism and feminism has been closely linked with a negative socialist legacy and has also been labeled a detrimental by-product of cultural modernism. This work sheds light on such issues in Poland, contributing to previous historiography on women in Central and Eastern Europe while providing a fresh perspective. 


\section{TABLE OF CONTENTS}

I. Introduction: What about Poland's Women?

Page 1

II. Polish Women: 1900 - Solidarity

Page 6

III. Solidarity, the End of Communism and Women in Transition

Page 18

IV. Abortion, the Church and Politics

Page 34

V. Women's Activism and the Concept of Feminism

Page 48

VI. Current Issues: Problems and Potential for Polish Women

Page 65

VII. Conclusions: The Unique Case of Polish Women

Page 76

VIII. Bibliography

Page 79 


\section{Introduction: What about Poland's Women?}

Since the fall of communism, historians have been observing, recording and analyzing the effects of political and economic transitions on women in Central and Eastern Europe. Stark divisions have arisen as to whether women gained access to new and better opportunities or they were stifled politically and burdened economically and socially. Statistics regarding women's employment and enrollment in higher education can suggest the former scenario while data regarding women's participation in elected government and the media's public discussion regarding contraception and childcare may indicate the latter reality. Though these debates may remain forever unresolved, the historiography of women's experiences before, during and after 1989 in Poland is enriched by a variety of attentive historical inquiry and writing as well as comparative consideration of neighboring women's experiences.

Women's involvement with the Solidarity movement, their critical contribution to its success, and their subsequent exclusion from political restructuring signified a critically trying and transformative time for Polish women during the 1990s. This exclusion and the disregard of women from many political arenas as well as changing attitudes and policy regarding women's issues from within Poland's governing bodies produced a restrictive social dynamic in which women were encouraged to return to a more domestic sphere by a variety of means. This changing climate manifested itself in a turn towards traditionally conservative, nationalist and religious views during the process of transition which marginalized women and helped shape the interestingly unique and contentious modern women's movement in Poland.

As in many other European and post-Soviet states, a notable feminist community has emerged in Poland and is abutted by further groups of men and women who eschew the feminist label while supporting women's issues and principles of equality in society. Conversely, there 
still remains a measurable anti-feminist sentiment within Poland's borders which has managed to establish and maintain restrictive anti-abortion laws and continues to marginalize women's issues by establishing traditional political and social norms based in Catholic and patriarchal frameworks as more appropriate and valuable to Polish nationalism and to society.

Such marginalization and restrictions on women's personal freedom and lifestyle choices create a sense of second-class citizenship based upon gender, which in turn, fosters discord in society by promoting inequality amongst citizens. By recognizing such discord and inequality and making record of it, society may begin to analyze history with the intention of improving conditions in the present and for the future. This work analyzes Polish women's issues (such as political activity, reproductive rights, and wage equality) and feminist activity as they developed and were affected by Polish women's recent history - in particular, by the Solidarity trade union movement and Poland's subsequent transition to a democratic, capitalist state.

Foremost, this work considers women's crucial role in Polish history, particularly in the Solidarity movement which forced a revolution of political and economic substance in Poland. The success of this movement, followed by women's subsequent exclusion from the new Polish political arena, was critical to the development of Polish feminism today. Therefore, this work will trace modern Polish women's history, set forth the characteristics, accomplishments and failures of Polish women's activism and establish the necessity and potential benefits of encouraging feminist principles in society on all levels. By building on the existing historiography, including Anna Reading's 1992 study on Polish women and Solidarity as well as Shana Penn's acclaimed 2005 work on the unrecognized women heroes of Solidarity, this work will contribute an updated and fresh perspective on the recent history of Polish women, feminism and potential for gender equality. 
With regards to the focal issue of gender, critics have claimed that the topic and classification of gender has been both under-represented and over-represented in scholarship. Feminist, post-feminist, and anti-feminist critics have responded both positively and negatively to the school of gender and women's history since its inception in the mid- to late-twentieth century and though as mentioned, the concepts of feminism and gender may remain controversial to some, the cumulative historiography has made considerable contributions to re-writing significant portions and perspectives within history. Women are critical actors and must be accounted for when examining events in history and politics - no time more so than in the past century.

As civil wars, world wars, and cold wars raged on, women were moving into the public sphere at unprecedented rates, acquiring the regard, respect and rights of their male counterparts. Perhaps the most critical periods of development for women's activism began with the early suffragette movements across North America and Europe during the early twentieth century and blossomed during the birth of women's history and gender studies during the 1960s and 1970s as the second wave of American feminism rejuvenated women's issues back to the forefront of both political and social dialogue as well as scholarship. This American women's phenomenon spread from North America across the globe and has come to be known as the core development and definition of modern women's activism and scholarship. In the past two decades scholarship representing women's history, current issues and transitional experiences has begun to explore the region of Central and Eastern Europe.

The focus of this work will examine perhaps one of the most interesting and potentially insightful instances of women's critically debated and appraised moves into politics and civil society during the revolutions of 1989 in Central and Eastern Europe as the great communist 
experiment collapsed. As governments fell and states began to transition to the democratic, capitalist countries they are today, women's participation in past nationalist struggles as well as their place in transition and in the future of society was received in various ways. To some, women's issues were in dire need of attention, threatening to create serious problems which had to be addressed; others considered women's issues as particularly unimportant - or even potentially detrimental to society if they gained recognition.

Poland's women fell into a particularly interesting and regrettable category. As primary operatives and coordinators of the Solidarity movement during the 1980s, Polish women could boast of many bright, effective, female leaders and organizers who ran the daily operations of the country's largest and most influential anti-communist trade union and social movement. As Solidarity succeeded and democratic transitions began, these women were soon relinquishing (and being forced to relinquish) their positions and power in political structures that they had acquired working for the national cause. Depending on perspective, this removal of women from political and power equations was either a natural consequence of Polish national victory or a tragic failure to advance women's socio-political position in Poland.

The obvious question on many minds is how these women failed to recognize their importance and the significance of establishing themselves in systems of political power during Poland's transition to democracy. In fact, by asking this question we may begin down many other related lines of inquiry: Did these women truly fail to recognize their own potential? Why would we say these women have 'failed' to develop and prosper politically? What was the social context of women's exclusion from politics and power during the early 1990s? What roles did the Catholic Church, the nature of Polish nationalism and Solidarity's male leadership have in excluding women? 
Finally, where are women now? By revisiting the historical legacy of women in Solidarity, examining the social, political and economic context of 1990s transition in Central and Eastern Europe, and applying the approach of gender in history to Poland's particular cultural tradition we may begin to gain further insight on the present situation of women and feminism in Poland. In this paper we will first return to the historical legacy of Polish women's history during the twentieth-century, particularly their participation in Solidarity; then we will examine the controversial issue of abortion laws, the influence of the Catholic Church, nationalism and political life in Poland. This study concludes by reviewing Polish women's organizations, feminism, politics and global perspectives on Polish women's issues. 


\section{Polish Women: 1900 to Solidarity}

To begin:

"In the words of a $19^{\text {th }}$ century critic, a Polish woman is very active in the life of her nation, participates in rallies and battles, but above all she suffers - as mother and wife, as fiancée and lover, as landowner and exile. She suffers pain in all varieties and fathoms the depths of human misfortune and disappointment."

The late nineteenth and early twentieth century was an extremely important formative time for Polish first-wave feminism. This period of forgotten history, denied its proper title and significance in deference to nationalist ambition, must be revived in public memory. As Poland began to modernize and transition from an agrarian to an industrial society many changes affected political and social norms; perhaps one of the most major changes was constituted by the issue of women's place in society, or the "woman question" which historian Robert Blobaum has described in his work. With urbanization, industrialization, political upheaval and cultural modernization taking root in Poland, questions regarding women's issues such as employment, dowries, marriage, fashion and displays of sexuality became popular topics in Polish media.

Stepping into the public realm as employees, migrants, activists and individuals created new opportunities and problems for women in Polish society. As these women's presence outside the traditional realm of domesticity increased, the "woman question" garnered more attention and controversy. At first, average women appearing in the public sphere were most concerned with their personal welfare - attaining paid employment, sustaining their family or individual lifestyles, and attaining literacy. More prosperous women from upper-class and intelligentsia were also moving into the public sphere to demand access to higher education, equal political rights and consideration. It is important to note that women were divided as to their priorities for moving into the public sphere; some were forced to do so by economic

\footnotetext{
${ }^{1}$ Urszula Tempska, "Double Marginality Or/As Double Indemnity?: "Europe” In The Prose of Polish Women," symplokē 5 (1997): 187.
} 
hardship, some by choice, though they did have common goals in achieving recognition and some measure of respect from their male counterparts.

Blobaum has noted in his research the unique situation which characterizes the public reception of this period of first-wave Polish feminism and women's activism during the transition from agrarian to industrial: "As this same transition also inspired the rise of modern political movements and mass organizations, particularly those of a patriotic and nationalist flavor, women's participation in them automatically drew unprecedented attention to the question of women's roles in the modern and variously imagined Polish nation and civil society." 2 This statement constitutes the first part of a uniquely Polish case in developing women's activism; the role of Polish nationalism during the early twentieth century was quite strong as Poles were experiencing yet another period of national oppression while they were occupied and controlled by Russian government. Acknowledging the lack of historiography regarding Polish women's political lives in the early twentieth century, Robert Ponichtera states, ... a large number of Polish women worked to achieve and then to defend Poland's national independence during the sixteen-year period between 1905-1921. Few actually took up arms. Yet in all three parts of partitioned Poland, women were active in every important political and social movement connected with the Polish cause. Even more interesting than the work they did, however, was their motivation, a blend of national consciousness and the search for equality. ${ }^{3}$ Polish nationalism emphasized unity and solidarity over individualism or group divisions, such as the separation of women's issues from those of the rest of society. The initial opposition of these movements - women's and nationalist - signified a particularly antagonistic relationship which would develop and soon add the component of religious tradition in formulating a unified anti-feminist movement in Poland.

\footnotetext{
2 Robert Blobaum, “The 'Woman Question' in Russian Poland, 1900-1914,” Journal of Social History 35 (2002): 799.

${ }^{3}$ Robert M. Ponichtera, "Feminists, Nationalists, and Soldiers: Women in the Fight for Polish Independence," The International History Review 19 (1997): 16.
} 
The second characteristic which contributed to the uniqueness of Polish women's development is the role of the Catholic Church in society. During the early years of the twentieth century as Polish women were stepping out into society, the Catholic Church was beginning to deal with how they would address this 'woman question' and what positions they would be inclined to suggest to their members. Blobaum suggests that the Church was set in opposition towards these transitions from their inception; he states, the Church was in "a position which in itself necessarily invited polemical response from radical populists who viewed the Church as a principle obstacle to rural 'modernization' and from feminists eager to challenge patriarchal definitions of morality."4

The Catholic Church's establishment as a patriarchal structure and its desire to retain this traditional organization were political incentives to retain the status quo. Morally and socially, the Church's teachings affirmed men in primary roles and had always relegated women to the periphery and supporting roles. Further reinforcing this gendered assignment on an educational and authoritative level, zero percent of theology degrees were conferred to women in Poland during the early twentieth century. ${ }^{5}$ Though women's roles were to be played out in the periphery and should be categorized as secondary to their husbands, fathers and brothers, the Church did encourage some women to participate in appropriate activities such as the newly formed rosary circles which were social opportunities outside of the home, thus expanding acceptable social behaviors beyond that which was previously supported. ${ }^{6}$

Even when faced with difficult opposition, Polish feminists and women's activists continued to demand the regard of their peers. As literacy spread throughout the region, greater

\footnotetext{
${ }^{4}$ Blobaum, 804.

5 Maria Cole, "Gender and Power: Sex Segregation in American and Polish Higher Education as a Case Study," Sociological Forum 12 (1997): 225.

${ }^{6}$ Blobaum, 803.
} 
calls for emancipation and equality came from the bottom-up. Blobaum has noted that this should come as no surprise considering, "the fact that these women had no choice but to rely upon themselves, especially if they had no choice but to seek their fortunes in the cities." "7 It would seem logical in this case that access to education and employment were of primary concern, as such access could provide women with further and better abilities to support themselves and their families. Ponichtera has argued that the main objectives of Polish women's movements in the early twentieth century were very simple, "improve the material condition of women (to make them less dependent on men), to open universities to women, and to obtain equal pay for women workers."

As previously discussed, it should be noted that some Polish women were also highly concerned with political equality, the right to vote and participate in government and social organizations. These women were, for a time, more unified in their approach and began several organizations to promote their cause including the Union of Equal Rights for Polish Women, which could boast of an effective central leadership, an insightful periodical and successful grassroots organizing as well as strong feminist organizers fighting for "equal civil and political rights for women throughout partitioned Poland."

To be sure there were just as many women opposed to the furthest or what they would consider most outlandish forms of women's emancipation and improvement. For many women activists the thought of a truly independent woman was absurd and unreasonable. Though women's activists fought for access to better education and employment, the end goal of these attainments would be to produce better wives and mothers, not better citizens or equals to their male companions. Women's employment was a matter of sustenance during the years before

\footnotetext{
${ }^{7}$ Ibid, 805 and Rzepniewska, "Kobieta w rodzinie ziemiańskiej," 40-42.

${ }^{8}$ Ponichtera, 19.

${ }^{9}$ Blobaum, 810 and Ponichtera, 22.
} 
they were married or extreme circumstances such as war. Higher education was a pursuit that could enrich women's lives by making them more aware of appropriate social opportunities and moral obligations to both their families and their nation.

In fact, women's access to higher education was an area which did seem to receive some measure of consensus amongst the Polish population, especially with encouragement and promotion by journalists, writers, and members of the intelligentsia. ${ }^{10}$ By the interwar period women in Poland attended coeducational universities and were "fairly well represented in the prestigious (higher paying, male-dominated) fields of study...indicat[ing] that gender barriers were relatively low in Polish higher education between the wars." ${ }^{11}$ This tremendous success in advancing women's education, and by proxy their careers, was a marked victory in the struggles of feminists and women's activists during the early twentieth century.

Unfortunately, the division between women fighting for limited access to education and employment and those women fighting for a more full-fledged political and social equality between the sexes contributed to the disagreements which continued to fracture and weaken feminist and women's issues movements prior to the First World War. Socialists challenged the women's movement with a 'class over gender' argument and nationalists were able to effectively challenge women by degrading their goals as un-patriotic, anti-Catholic, sinister and silly. The press encouraged public opinion to disregard feminist principles as "cultural immaturity" and feminists themselves as "hysterical vandals." 12 Most important was the union of Catholicism and nationalism which created an unstoppable tide against feminism in Polish society.

When nationalist and Catholic critics of feminist and women's issues organizations united, their major tactic was the adoption of the Matka Polka image to define the best type of

\footnotetext{
${ }^{10}$ Cole, 221.

${ }^{11}$ Ibid, 226.

12 Blobaum, 813 and “Amazonki XX wieku,” Kurjer Warszawski, no. 76 (16 March 1912), 3-4.
} 
Polish woman. Blobaum has argued that "the nationalist adaptation of the 'Matka Polka' to the movement's 'modern' needs was a part and parcel of the 'catholicization' of Polish nationalism, a process already quite visible on the eve of the Great War."13 $T$ There is, perhaps, no better description of the unity between these two characteristics of Polish society; nationalism and Catholicism were always entwined as points of strength in a struggling nation-state but it was at this point in history when their unification bonded pointedly against a product of socio-economic modernization, namely feminism.

This powerful bond and the inescapable ideal of the Matka Polka have plagued Polish feminism ever since. In fact, it was this unification of nationalist and Catholic interests against feminism which has strengthened over time and has been able to achieve significant success in thwarting feminist policy-making attempts and discrediting various other manifestations of feminist activism. In the years immediately predating World War I, it was opposition such as this along with preexisting divisions within the women's movement which resulted in its eventual overshadowing. As the war began, inevitably social and political divisions and the so-called 'woman question' within partitioned Poland were put aside by some to prioritize the war effort and look forward to a time when Poland may once again be united.

In the inter-war period, during the Second World War and in the communist period afterwards, history seems to have forgotten this strong and remarkable period of women's history in Poland. Even today, some Polish scholars will claim that there is no strong tradition of women's activism in the early twentieth century and that women's rights were handed to them on a silver platter at the end of the First World War. How could this history have been so dismissed? Blobaum contends that this forgotten era of women's history is "bound up with the long unchallenged dominance of the master narrative of twentieth-century Polish history shaped,

${ }^{13}$ Ibid, 809. 
above all, by the political agenda of Polish nationalism. ${ }^{14}$ In rediscovering this period of formative, strong first-wave Polish feminism historians and readers alike will contribute to a deeper understanding of the development and difficulty embracing feminism in Poland.

Just as Warsaw was the cultural capital and epicenter of first-wave Polish feminism, so was it the center of public, documented women's experiences during the First World War. As Polish territories emptied of men while the war raged, women remained in Warsaw and other cities to find work, comfort and family. Inevitably, women's wartime experiences were vastly different from their male counterparts and interestingly they received considerable attention from the Warsaw press and media outlets. Though of course there were the issues of migration, unemployment, prostitution, rape and starvation to address as women's issues during the war, a recent article has brought propaganda and the media's attention towards Warsaw's women forward as an interesting issue for study.

Though the first-wave of Polish feminism had for all intents and purposes ended as the First World War began, it was followed by a continued commitment on the part of some women to the cause of political equality and by others in the form of a deep commitment to the various issues (education, housing, employment) which they considered most practically valuable for women. The Polish press often included news pieces on the "woman question" during both the First and Second World Wars which comprised a variety of praise, scorn, intelligent debate and buffoonish derision.

What was interesting about Poland, Warsaw in particular, during the First World War is that while it experienced a "demographic feminization" as did other major cities in Europe, there

\footnotetext{
${ }^{14} \mathrm{Ibid}, 806$.
} 
was also a simultaneous drop in women's employment which was unique to Poland. ${ }^{15}$ This interesting combination of an excess population of women with no employment created a difficult situation in which many women and their children were threatened with homelessness, starvation and other such hardships. Inevitably, some of these women turned towards prostitution and less traditional types of work to earn their living while others, including war widows and wives of men fighting claimed special privileges exempting them from paying rents or utilities.

Moreover, it is important to note that there was some growth in the feminist movement during the First World War. It happened that the women who maintained their commitment to feminist ideals and activity pre-war were "joined by a much larger group of feminists of wartime circumstance. The latter can be defined as the female members of prewar social and cultural conservative elites whose perspectives and, ultimately, demands were shaped by their wartime experience in philanthropy, social work and public assistance." ${ }^{16}$ These new feminists viewed women's and children's suffering, European disaster, disease and war atrocities with a critical lens; though resolving problems of such magnitude had always been the concern of male politicians and military leaders, women had served on the front lines ameliorating suffering, nursing and organizing immediate assistance to those suffering. Wartime experience from the First World War encouraged some women to view their work and potential roles in social assistance as truly valuable and deserving of political recognition.

After the war, Polish women continued to fight for Polish independence and safe establishment of its borders. Their eagerness to continue fighting for Poland is tied to a number of significant reasons: first, the right to vote was granted to Polish women in 1918 as the war had ended and Poland declared its independence; second, many Polish feminists believed that their

\footnotetext{
${ }^{15}$ Robert Blobaum and Donata Blobaum, "A Different Kind of Home Front: War, Gender and Propaganda in Warsaw, 1914-1918," in Propaganda and the First World War, ed. Troy Paddock (forthcoming with Brill, 2012 ), 2. ${ }^{16}$ Ibid, 4.
} 
own independence was linked to that of their nation. In his research scholar Robert Ponichtera went so far as to claim, "In fact, many women believed that only the re-creation of an independent Poland would bring about their emancipation." ${ }^{\prime 17}$ And so, women fought for Poland for many reasons, chief among them their dedication to their nation, their state and their homes. Explicating further, Ponichtera describes Polish women's involvement with social and political activism:

The perception of impending political change prompted women...to call for social change. [W] omen assumed that the end of the war would lead to democracy and equality; not only would this new age right the wrong of the partitions, but it would also confer equal rights upon all citizens of the new state. Thus, emancipation and national independence had combined: feminists perceived the reconstructed state as the vehicle for improving the condition of women. ${ }^{18}$

These women remained dedicated to national causes and envisioned themselves to be key figures in the establishment of the new state as well as important figures in planning for the future. In 1920 the president of the National Organization for Women, Madam Sobanska, recognized the tragic history and expressed optimism at the future remarking on the power of patriotism, "Beneath all the surface variations, past and present, in the social, economic, and political structure of my long-martyred country, there has persisted the unalterable welding force of Polish patriotism. On that we build."19

Undoubtedly, World War II was cataclysmically devastating not only for Polish women, but for the entirety of Europe and nearly the whole world. The case for Poland was particularly devastating and unique as it was quickly invaded and fully occupied by the Nazi regime. Polish citizens again lost their independence and were suffered to experience a most brutal regime which persecuted Poles, Slavs, Jews, men, women and children equally. The violence of the Holocaust and daily wartime experiences left little room or meaning for any sort of activism

\footnotetext{
${ }^{17}$ Ponichtera, ibid, 16-17.

18 Ibid, 24.

${ }^{19}$ Charlotte Kellogg, "Poland's Women," The North American Review 212 (1920), 511.
} 
aside from resistance in the Central and East European region. However devastating the war was, those years represented a major shift in workplace demographics: "wartime mobilization of women bore the appearance both of an alignment between women and men and of a blurring of the visual boundary between masculinity and femininity.,20

As the war finally came to a close in 1945 it became clear that the new, super-power Soviet Union would claim responsibility to oversee re-building and recovery in Poland as well as eventually absorbing the nation entirely. After their brief years of independence and a horrific wartime occupation, Poland was once again subjected to a lengthy and oppressive period of subjugation. Political, economic and social activities were closely regulated in Poland as new Soviet plans for the country took form.

Historian Penny Summerfield has described the "blurring" of gender norms in the workplace during WWII, but goes on to claim that what might have really been taking place was a "polarization of the sexes" accompanied by "men's hostile and suspicious reactions to what they perceived as encroachment on their territory. ${ }^{, 21}$ In the aftermath of these changing social dynamics it is imperative that the historical record conveys a realistic portrait of society's progression. In reality, conditions for women during the communist period from 1945-1989 swung a wide berth of description, though many remember the period as an era when women were given and guaranteed equality. Initially, during the Stalinist era it appears that the state "offered women a set of multiple, yet limited, identities: women could be workers, mothers, wives, labor heroines, or political activists." ${ }^{, 22}$ New opportunities and encouragement for women to participate in traditionally male spheres of work were received somewhat well, initially.

\footnotetext{
${ }^{20}$ Penny Summerfield, "Gender and War in the Twentieth Century," The International History Review 19 (1997): 5.

${ }^{21}$ Ibid, 5 .

${ }^{22}$ Małgorzata Fidelis, "Equality through Protection: The Politics of Women's Employment in Postwar Poland, 1945-1956," Slavic Review 63 (2004), 303.
} 
Inevitably, the post war period was home to many Polish families without fathers and husbands who were lost in the war. Many Polish women were tasked with a life of raising children, caring for their families, maintaining the household and working to provide for everyone. With new opportunities for better and more skilled employment now available, women moved into the working world eager to support themselves and to contribute to national recovery and growth.

Even within these new opportunities for employment there were many restrictions as to the type, hours and conditions of work that women were allowed to perform. Protective labor laws were enacted to prevent the exploitation of women in the workplace, and to assure their safety with regard to the "female psyche," "psycho-physical characteristics," and of course, their reproductive health. ${ }^{23}$ These laws were received most enthusiastically by all factions of society. Though they may today be interpreted as paternalistic and absurd, protective labor laws for women were considered "highly progressive and advantageous to women. ${ }^{, 4}$ In this way it is easy to see the strange but accepted combination of tradition and modernization, of native ideology and foreign import. Polish gender roles and norms were modified to a certain extent, to accept a more liberal position of equality between the sexes whilst still maintaining traditional regulations in a legal form, backed by science of the time.

Following the Stalin's death in 1953, the process of de-Stalinization began and included many labor reforms which affected women's labor and social roles in the People's Poland. The chance to loosen Soviet influence, however slightly, provided an opportunity to reaffirm more traditional Polish gender norms in the workplace and at home. More elaborate lists of prohibited jobs for women were enforced and even the League of Women, which had previously supported all types of women's employment, changed its tune suggesting that women's double burden of

\footnotetext{
${ }^{23}$ Ibid, 307.

${ }^{24}$ Ibid, 305.
} 
work at home and in the labor force put them on more unequal footing than before they began work outside of the home. ${ }^{25}$ It seemed that de-Stalinization had begun to encourage a return to the home and to the most important calling for women, motherhood. Appropriate work was certainly still considered an acceptable pursuit for women, though more in the context of the early twentieth century, as a choice for unmarried, childless women.

Now that the damaging era of Stalinist policies had passed, relieving Polish citizens of the threat against their social organization and tradition, the 1960s and 1970s began a period of alternating calm and upheaval against communism. The initial frustration of subjugation to Soviet control and the continued reminders of non-Polish ideology and modernization caused upheaval in society, perhaps best exemplified in the study of women's role in society and employment. By the 1960s in Poland, it seemed that women's employment and issues were only being discussed and advocated by sociologists and further into the 1970s women were almost exclusively discussed in combination with and in the context of the traditional family. ${ }^{26}$ This decline in public attention to the 'woman question' has been attributed to the lull in feminist activity during the postwar years. Even throughout the lull, there were women activists advocating for better opportunities, social welfare and women's political activity. With the economic crises, workers' strikes and political adjustments of the 1970s, women kept themselves involved in Polish civil society. As political and economic opposition to the communist partystate erupted in the Solidarity years of 1980-1981, Polish women began their crucial involvement in the trade union turned revolution that would change their country.

\footnotetext{
${ }^{25}$ Ibid, 321.

${ }^{26}$ Małgorzata Fidelis, Women, Communism, and Industrialization in Postwar Poland (Cambridge: Cambridge University Press, 2010), 243.
} 


\section{Solidarity, The End of Communism and Women in Transition}

As evidenced by the introductory chapter, Poland is a state with a lengthy history of struggling for its independence. Subjected to centuries of conquest, occupation, and oppression, the vast majority of the twentieth century was spent under Russian, Prussian, Austrian, German or Soviet control. By 1980 it seemed that Poles were poised to make a determined effort for their national cause once more. Unrest and Polish resistance to the communist government installed after the Second World War was nothing new; there had been protests, underground movements and social tensions since 1945 but it seemed that by the eighties these protests had gained such momentum in popularity, membership and meaning that the conflict between Poles and their government had reached a breaking point. Historian Shana Penn described the turn of events:

In August 1980, after a decade of protest and strikes, an estimated one million workers gathered in factory halls and shipyards across Poland to demand restoration of their human rights. Their collective apostasy created Solidarity, the first and only free trade union movement of the Eastern Bloc. By the first anniversary of Solidarity's creation, more than one-third of Poland's adult population, approximately ten million men and women, had joined Solidarity and helped to establish political clubs; adult education programs; legal services; an independent press; and an array of film, theater, literary, and artistic offerings. ${ }^{27}$

Solidarity's success in reaching wide strata of the Polish population was due not only to public unrest with the government's oppressive operations, but was also intertwined with the inclusive nature of the movement which in essence created a civil society critical of the partystate operations and agenda. If for a brief time these alternatives and the movement itself were recognized and to a certain extent accepted by the government, it wasn't long before Solidarity became too strong an opposition to be allowed to operate openly and in competition with the government. General Wojciech Jaruzelski’s declaration of martial law on December 13, 1981

\footnotetext{
${ }^{27}$ Shana Penn, Solidarity's Secret: The Women Who Defeated Communism in Poland (Lansing: University of Michigan Press, 2005), 3.
} 
culminated in security forces rounding up thousands of political prisoners, including many members and leaders of Solidarity.

Recognizing the need for able-bodied leadership as well as directions for the support systems required to keep the movement alive, Poland's women stepped forward as they had done each time the national cause called for their assistance. Though trade unions and the workplace have traditionally been masculine-dominated arenas, women were constantly playing crucial roles in Solidarity's organization and operation. When many of their male counterparts were incarcerated, the tasks of running operations and logistics of the movement as well as publishing the opposition newspaper were delegated to the charge of Polish women. ${ }^{28}$

Women such as Ewa Kulik went in search of Solidarity leaders in hiding, helping to protect them while simultaneously communicating many messages and directives to the underground press and other organizers. Helena Łuczywo and others took over publishing one of the most important underground newspapers, Tygodnik Mazowsze, which served not only as an opposition news source, but as a beacon of hope and a call to arms for Solidarity. Many other women contributed to Solidarity's cause and took on responsibilities of facilitating communication, organizing meetings, promoting acts of resistance, hiding Solidarity members and a variety of other activities which contributed invaluably to the eventual success of Solidarity's program and ideals in Poland.

As far as women's contributions to the Solidarity movement are concerned, scholar Shana Penn has focused on two main sources of their operations which have been considered crucial to the success of the movement: grass roots civic organizing as well as logistics and publication of Tygodnik Mazowsze. As a comparative reference, East German women's involvement with their respective, growing movement of state criticism was more limited to

\footnotetext{
${ }^{28}$ Małgorzata Fidelis, "Poland," The Oxford Encyclopedia of Women in World History (Oxford, 2008).
} 
activity in the "New Forum" where demands were made for more a more humanist socialism by means of prayer and sarcasm, peaceful protests and social pressure on the government. ${ }^{29}$ The historiographic discussion of women's involvement in the East German 'Gentle Revolution' indicates that their role was somewhat less literally active. Scholar Donna Harsch's work describes the domestic component of German women's influence on political transitions of 1989; focusing on East German women's domestic concerns and dissatisfaction by arguing that, "Ordinary women... were the main agents of the revenge of the domestic. They demonstrated that the routines, decisions, pleasures, and pains of the everyday are rooted in domestic relations," which ultimately concluded with the loss of government legitimacy when citizens recognized that the government would or could not respond appropriately. ${ }^{30}$

Returning to Poland, some of the most typical activities Solidarity's women engaged in were active tasks “to reconnect Solidarity's nationwide network of contacts, to protect the leaders in hiding from the secret police, to arrange meetings, and to smuggle money and equipment into the country." ${ }^{31}$ These general operational tasks were considerably more important than the historic record would indicate; these types of tasks are too often taken for granted as being of an administrative or logistical nature rather than those of leadership and message. The irony, of course, being that any leadership and its respective message require such infrastructure in order to propagate and further its cause.

Regarding women's other contributions, the publication of Solidarity's newspaper Tygodnik Mazowsze was perhaps the most critical and valuable contribution of the organization's women volunteers. In fact, the operation of the newspaper's publication was entirely coordinated

\footnotetext{
${ }^{29}$ Reinhart Schönsee and Gerda Lederer, “The Gentle Revolution,” Political Psychology 12 (1991), 313.

${ }^{30}$ Donna Harsch, Revenge of the Domestic: Women, The Family, and Communism in The German Democratic Republic (Princeton: Princeton University Press, 2007), 318-319.

${ }^{31}$ Penn, 10.
} 
by women. The secret police as well as the Polish public would have been quite surprised to find out that "the leading newspaper of the 1980s underground was a female run enterprise and that the thousands of people who helped produce and distribute it took their instructions from an allwoman editorial team. ${ }^{32}$ The work of putting out this publication was a tremendous accomplishment and an obvious necessity in coordinating the Solidarity movement after the declaration of martial law.

Perhaps the most vital role which escaped Solidarity's women was the status of formal leadership. As women worked initiating, operating, problem-solving and maintaining various aspects of the movement during the 1980s, they never acquired measurable power or influence comparable to their male counterparts. Historian Barbara Jancar described the power discrepancies with the following statistic: "As one rose in the Solidarity hierarchy, the numbers of women diminished. Only 7.8 percent (69) of the 881 delegates to the Solidarity Congress [in September 1981] were women; only one woman sat on the National Executive [Committee]."33 Women's work and leadership was not viewed in a gendered lens, particularly by their male peers at the time. Women's contributions were often taken for granted and if they were analyzed, it was through a nationalist and unified perspective, especially by men. Though there was no formal recognition of women as leaders within the movement, their work cannot be regarded as less than vital to the success of Solidarity.

Furthermore, it is important to note that women's involvement with Solidarity occurred in conjunction with the variety of responsibilities they already held in their personal lives. Beginning in early twentieth century and continuing through the time of world wars, into the communist era and beyond, Polish women confronted the so-called "double burden" of working

\footnotetext{
${ }^{32}$ Penn, 10.

${ }_{33}^{33}$ Barbara Jancar, "Women in the Opposition in Poland and Czechoslovakia in the 1970's," in Women, State, and Party in Eastern Europe, ed. Sharon Wolchick and Alfred Meyer (Durham: Duke University Press, 1985), 169.
} 
both inside and outside the home. Added to this double burden, women's dedication to activism and supporting Solidarity created a situation which forced these women to sacrifice their time, well-being and quality of life for the causes they believed in.

It is appropriate to comment and compare the Polish handling of women's 'double burden' with that of the East and West German policies. Simply put, "West German policy deterred women, especially mothers, from paid work," thus eliminating the problem of double burden socio-economic pressures on women. ${ }^{34}$ The East German solution to pressures of the double burden was more complex, offering both protective employment laws for women and pro-natalist incentives for women who wanted to have children and work. In fact, scholar Barbara Einhorn has claimed that, "it could be argued that the GDR went furthest of the state socialist countries in its policies towards women as producers and reproducers." 35

As scholar Anna Titkow described, this double burden and change in traditional, societal roles for women amounted to a "loss of a chance for fundamental changes in the essential social and cultural identity of Polish women," 36 as they were regarded and treated relatively the same as in previous years while taking on considerably more work and responsibilities. Maintaining paid jobs outside of the workplace, caring for their families and facing economic hardships which necessitated their work outside the homes was an extremely difficult situation for many women, some of whom had been struggling with this reality for many years and was equally difficult for women forced into this new way of living by economic crisis.

\footnotetext{
${ }^{34}$ Rachel A. Rosenfeld, Heike Trappe, and Janet C. Gornick, "Gender and Work in Germany: Before and after Reunification," Annual Review of Sociology 30 (2004), 109.

${ }^{35}$ Barbara Einhorn, Cinderella Goes to Market: Citizenship, Gender and Women's Movements in East Central Europe (New York: Verso, 1993), 35.

${ }^{36}$ Anna Titkow, "Political Change in Poland: Cause, Modifier, or Barrier to Gender Equality?" in Gender Politics and Post-Communism, 253.
} 
Even today with Shana Penn's insightful book detailing many important women as the unsung heroes of Solidarity and the end of communism in Poland, it may still be difficult to know the full extent of women's participation and contribution during the 1980s. At the time, these women stubbornly refused a gendered analysis of their participation and stoutly resigned their actions to the category of doing whatever was necessary - not something heroic. They denied labels of feminism and claimed that promoting women's issues was not any part of the motivation for their active political lives within the anti-communist movement. This is certainly not surprising for many reasons, chief among them the long tradition and influence of Marxist theory within the Central and East European region which identifies class as the true division in society (not gender or ethnicity) as well as the underlying patriarchal structure of Polish nationalism and support of the Catholic Church, which helped found the movement.

This activity, the efforts and struggles these women took upon themselves was an obligation they felt would be recognized and rewarded by a Polish national victory against externally sponsored oppression. Even given women's lack of formal leadership roles, the shared responsibility of both male and female workers in combating the repressive tactics by Jaruzelski's regime, in pursuing Solidarity's work and shared goals could and should have been an indication of gender equality within the movement. In travail and burden, just as in freedom and victory, Polish men and women would stand together united by dedication to their country and its cause.

As for women's recognition as critical actors and organizers of the Solidarity movement, the media and public memory did not comment greatly, if at all, on women's involvement for sometime after Poland's independence and early transitional years. For many years there was a 'myth' of the Polish men's victory over communism; Solidarity's male leaders such as Lech 
Wałęsa stood in the foreground as a national leader and victor over communism whereas Solidarity's women were all but forgotten.

Fault for this oversight can be allocated to a variety of sources, first to the international media. As late as the early 1990s after Poland's independence, researching the topic of women in Solidarity would have yielded little to no results. Penn described her experience in preparing to investigate the topic, "from these [books, photographs, media] sources the only conclusion one can draw is that all of Poland's opposition leaders were men - handsome men, at that, and groomed to appeal to the Western press: bearded, brawny, big-shouldered hunks with the defiant, charismatic stance of heroes." ${ }^{37}$ Had the international media covered these women's involvement in the revolution more thoroughly, or at all, it may have sparked interest and recognition in women's contributions to and role in Polish society. As scholarship in the Central and East European region had no strong tradition of gendered examination and analysis of history, it would have been beneficial for scholars across the world to have been aware and gained interest in the topic much sooner, fostering a collaborative and insightful new subject for both Polish and international historiography and public record.

This initial failure of the media to fully report on the participants - both male and female working in the Solidarity movement during and especially after 1989 was not only irresponsible and disappointing but also harmful to the memory of Polish women's history in addition to future women's activism. By neglecting to report and record women's participation, the quality of scholarship on the topic of Solidarity through the early 1990s was diminished and the public perception of women in Poland was not representative of historical events. Was it the case that these women were to a certain extent complicit in remaining silent? Or, should it be considered that their "strategy of invisibility, so effective in the underground, worked too well" to be easily

\footnotetext{
${ }^{37}$ Penn, 5.
} 
overcome $?^{38}$ The truth must fall somewhere in between. The longstanding tradition of women's involvement in nationalist, political activity in Poland had always refused an analysis or description of gender equality motivation, thus continuing into women's participation in Solidarity. Those women who did desire and call for recognition in the fight to achieve national independence were few in number and easily ignored by likeminded politicians, newly formed press agents and an over-stimulated population, still caught up in the celebrations of independence.

If most Polish women were not expecting a separate recognition or reward for their contribution to Solidarity, it was only logical to expect that these women, like their male counterparts, would be included and embraced to some extent as part of the new leadership structure during transitional processes. In reality, the opposite occurred. Scholar Shana Penn has described the quick turn of events: "A critical moment arrived, a moment when Polish women had an opportunity to step forward and demand political power for themselves as a social group. Unfortunately, the barriers to empowering women on new terms within a new democratic society proved to be simply too high." ${ }^{39}$ Furthermore, it should be noted that there was no unification of Polish women as a social group or a consensus on how they could or would respond to political issues in a significant way. These barriers would prove difficult and lasting as Polish women's groups organized throughout the following decades.

With the collapse of the Soviet Union in 1989 and Poland's independence, new political elites were born; they were male, traditional, conservative, and Catholic. Beginning to understand how such a large-scale, national transition could take place without the participation of women as recently as 1990 is somewhat difficult to imagine from a Western perspective. By

\footnotetext{
${ }^{38}$ Penn, 13.

${ }^{39}$ Ibid, 262.
} 
examining the existing scholarship on the subject it is possible to track the progress and reveal turning points in the legacy of Polish women's participation in Solidarity.

By the mid-1990s, historiography in the field had firmly placed women into the narrative of transitional Central and Eastern Europe without delving into a deeper analysis of women's impact in bringing about and dealing with the aftermath of that transition. Padraic Kenney made a call to scholarship with an article in 1999, where he noted the "fundamental weakness in the historiography of workers' unrest in the Polish People's Republic. That research has generally portrayed workers as more or less a single group," lacking the strong differentiation that gender roles (particularly in the domestic sphere) create between male and female workers. ${ }^{40}$ If Kenney's article primarily analyzes the effects of gender differences during the communist period, his assertions provide an interesting basis for postulating that women would have had a larger role in politics had they demanded it. Kenney argues, "women defined themselves also as workers, as consumers, and as Poles. Yet each of these identities acquired a certain power as a result of the conjunction with gender: a woman worker was more threatening than a 'worker,' a mother-worker was the most dangerous of all. ${ }^{41}$ These new roles were threatening because they exemplified women to be more than reproducers and showcased their ability and existence functioning in the role of worker which had always belonged to men. The act of participating in the labor force had long been a qualification for recognition and the right to participate in political and economic decision-making within society. Polish men were threatened when they found themselves in the company of women, continuing in their roles of mother and wife, but also working outside the home and demanding the same consideration and rights that were always an exclusively male privilege.

\footnotetext{
${ }^{40}$ Padraic Kenney, "The Gender of Resistance in Communist Poland," The American Historical Review 104 (1999): 400.

${ }^{41}$ Ibid, 402-403.
} 
Since then, what Penn and other historians have attempted to do is to provide a better understanding of women's participation, their recognition (or lack thereof), and their refusal to distinguish themselves as women within the Solidarity movement during the post-communist transitional period. ${ }^{42}$ At present we will attend to women's contributions to Solidarity in Poland during the 1980s, leading into the 1989 elections and their place in the beginning of transitional processes. The historical context of women's action and lack of recognition for their involvement with the Solidarity movement is crucial to understanding the development of Polish women's place in society as well as feminist activism.

As mentioned, Shana Penn's book Solidarity's Secret: The Women Who Defeated Communism in Poland is perhaps the best publicized and most important work on identifying women's contributions to the Solidarity movement in Poland during the 1980s. This groundbreaking work employed a narrative format to introduce key women leaders in Solidarity, showcase their brave and tireless work in the anti-communist resistance and highlight their rewards and punishments as democratic Poland was established. The personal interviews conducted in Penn's research give wonderful and invaluable insight into Solidarity's female leaders as well as our current understanding of women's position in Polish society. Ties among cultural tradition, religion and nationalism are woven together intricately to create the tone in which Penn sets her story; it is in this tone in which Solidarity's women identify themselves and describe the necessity of their actions, placing the pursuit of what they believe is a greater cause (Solidarity) ahead of their lives, needs - and eventually their position in society.

One of the most powerful aspects of Penn's writing is her ability to describe the daily lives and major concerns of Solidarity's women in a way which conveys the seriousness of their situation and how these conditions are certainly representative of the larger female populations

\footnotetext{
${ }^{42}$ Penn, xiii-xiv.
} 
within Polish society. Here she describes the women who began running the underground newspaper of Solidarity to bolster the movement and provide reliable news to its members:

Like most Poles who had watched the labor movement grow into an entity powerful enough to challenge the authoritarian regime, Helen Łuczywo and company were keenly aware that it was the people - individuals with a common goal - who had given Solidarity its life. They built their plans on the shared certainty that the people would also ensure Solidarity's survival. ${ }^{43}$

As women risked their personal safety and made sacrifices for Solidarity's cause, it is worth a further look at what they were doing for the movement and why they felt compelled to contribute as they did. Unfortunately, it remained difficult to even recognize women's involvement with Solidarity for many years after the fact. Returning to 1992, Anna Reading's book, Polish Women, Solidarity and Feminism was an early, English-language study of Polish women in society and in transition. In the chapter entitled, "Solidarity for Whom?" Reading relates a brief history of Solidarity without once mentioning women's participation. The chapter does go on to describe women's involvement, stating, “After August 1980, however, women participated less and less in the actual strikes and acted more as 'stay-behind' forces at home, giving support thorough their men." ${ }^{44}$ This type of statement, if acknowledging that women did participate, in some way, in some location, demeans their work by classifying it as 'support.'

Unfortunately, this type of statement and the idea that women were working by simply helping 'their men' was a common perception of women's involvement with Solidarity. Acknowledging that women were members of the union and claiming that they only contributed on the periphery without taking leadership roles was the norm for historians, transition watchdogs and international observers during Poland's transitional years surrounding 1989. This trend can also be tied back to the failure of media to fully report on women's involvement in Solidarity, as previously mentioned. In any case, the beginning of the important work

\footnotetext{
${ }^{43}$ Penn, ibid, 149-150.

${ }^{44}$ Anna Reading, Polish Women, Solidarity and Feminism (London: Macmillian, 1992), 65.
} 
documenting the true extent of women's work in Solidarity came from these very historians and observers; noting women as absent from these processes and questioning the reasons why comprised the inception of modern Polish women's history. Reading stated, "In the nineties Solidarity acts as both a union and a political party and women's exclusion from both is blatant...This silence in itself is significant." 45 In excluding women from the union, Solidarity became inaccurately portrayed in the public image and in history; in excluding women from the political party, Solidarity narrowed the legitimacy of its agenda and perpetuates detrimental, patriarchal structures.

Though these Polish women were not recognized in the public media and scholarship of the time, Shana Penn argued that, in fact, Solidarity's women "held the power of numbers and influence necessary to make demands, but they lacked the drive and the know-how to exercise it." 46 There is certainly some historical evidence to support her claim, namely the fact that women failed to set and achieve further goals during the Round Table Talks. However, these intelligent, determined women were able to run underground presses and take over operations of the Solidarity movement when male leadership was arrested and imprisoned; it is disrespectful and irresponsible to assume that they were intellectually unable to stake their legitimate claims to political acknowledgment and consideration, though by and large that is precisely what happened. Was there an historical legacy or representation of inequality between the sexes that could explain this type of thought?

Within communist ideology it is well established that women and men should be considered equal comrades and citizens. However, as is often the case, the disconnect between ideology/policy and social reality were stark in communist Poland. Małgorzata Tarasiewicz

\footnotetext{
${ }^{45}$ Reading, 66.

${ }^{46}$ Penn, 269.
} 
noted this in an article from 1991: “Over the past forty years women's organizations were treated instrumentally, and though the legal system could have been considered pro-feminine, in Poland...there was a great discrepancy between the legal system and social reality." ${ }^{47}$ Following the wave of political liberalization of 1956 (including most notably the legalization of abortion), state policies towards women began to narrow the definition of appropriate work and activities for women. ${ }^{48}$ As previously mentioned, new protective labor laws inhibited some women from pursuing work when, how and where they were accustomed to. These newly established restrictions created a "privileged" situation for women which was established to protect their feminine physiology and child-bearing capabilities - authorities even went so far as to claim that "driving heavy machinery may cause the uterus to fail." ${ }^{49}$ Even in the midst of such discrimination and inequality masked by official political rhetoric, women's role as integral participants in the Solidarity movement as patriotic, anti-communist protestors and leaders was not diminished.

Though women had expected and been accustomed (at least rhetorically) to politically assigned gender equality, while living in an unequal reality, the decline of women's position in society in the post-communist period did result in an element of shock and frustration amongst many female Solidarity participants and even more women at large. In the view of transitional processes some women began noticing the oppressive tendencies that had discreetly defined the communist period as well as new types of oppression that would soon enter their lives. Some women vocalized their frustration as Poland's new, democratic government was established:

\footnotetext{
${ }^{47}$ Małgorzata Tarasiewicz, "Women in Poland: Choices to Be Made," Feminist Review 39 (1991): 183.

${ }^{48}$ Ewa Hauser, Barbara Heyns and Jane Mansbridge, "Feminism in the Interstices of Politics and Culture: Poland in Transition" in Gender Politics and Post-Communism, ed. Nanette Funk and Magda Mueller (New York: Routledge, 1993), 259.

${ }^{49}$ Ibid, 260.
} 
"Instead of building a pluralistic society, we have just replaced quasi-religious Marxist ideology with the only one right doctrine, namely, that of the Catholic Church." ${ }^{50}$

This new doctrine was extremely detrimental to women's rights and their status in society. Following the new government's establishment, a series of discriminatory legislative propositions were enacted, restricting the rights and freedoms of women across Poland: in 1993 abortion was severely restricted, maternity leave was extended and became mandatory, and the retirement age for women was lowered, thus reducing the size and value of pensions they would be eligible for upon retirement. ${ }^{51}$ The division in women's reception of these new laws was stark; feminists rejected the laws as discriminatory and paternalistic, though many conservative women viewed the laws as appropriately protective and advantageous to women and family prerogatives. Pressured politically and socially, women were returning to roles more traditionally seated in domestic, private spheres of life.

With further examination of the immediate post-communist era it becomes easy to see how the pattern of traditional, patriarchal, conservative and Catholic ideals and legislation reappeared and became dominant in political discourse. A reaction to agendas and 'un-natural' ideologies about women during the communist era was simple: it must be rejected in favor of something more Polish. In the view of conservative elites, the promotion of national unity and tradition will outweigh unnecessary focus on issues of gender equality since it will benefit all of society. One scholar described the situation, "This political transition has brought many

\footnotetext{
${ }^{50}$ Urszula Nowakowska, "The New Right and Fundamentalism" in Ana's Land: Sisterhood in Eastern Europe, ed. Tanya Renne (Boulder: Westview Press, 1997), 26.

${ }^{51}$ Fidelis, "Poland."
} 
necessary positive changes, but, unexpectedly, it has also brought negative changes, especially for the condition of women." 52

Was this type of knee-jerk reaction in rebelling against communist ideology and Jaruzelski's regime enough to explain women's failure to move into the public sphere as a unified and politically relevant group in society? Surely there were other factors which influenced the transformation of former opposition leaders into politicians and determined the distinct exclusion of women from this process. Why would men who worked side by side with their female opposition counterparts for nearly a decade suddenly choose to exclude them and downplay their invaluable contributions in fighting communism? The explanation for Polish women's exclusion from political life in 1989 and the early 1990s is straightforward, as are nearly all instances of women's oppression in modern history. Opportunism, lack of historical reference and unchallenged patriarchal structures are strong motivations and explanations for men's actions of disregarding women when political, social and economic power is at stake.

For the men of Solidarity in Poland, removing women from the new political equation was in some ways a logical decision but could also be interpreted as an unconscious one; formally including women as a sub-group of Solidarity in negotiations with the government and later in forming a democratic government and institutions would complicate matters, unnecessarily from the male leadership's perspective, though the initial thought of including women may never have even occurred to them. There is also the matter of Solidarity's anticommunist stature and the perceived "leftist" nature of feminist issues. ${ }^{53}$ Scholars have argued that the association of feminist ideals with communist egalitarianism created problems for female activists attempting to advance women's issues in the Polish public sphere.

\footnotetext{
${ }^{52}$ Wanda Nowicka, "Ban on Abortion in Poland. Why?" in Ana's Land: Sisterhood in Eastern Europe, ed. Tanya Renne (Boulder: Westview Press, 1997), 42.

${ }^{53}$ Hauser, et al., 261.
} 
Regardless of the political climate and social transformations it is easy to discern that the legacy of women's participation in the Solidarity movement was underrepresented by media, scholarship and the public memory before being revealed in Shana Penn's work. This legacy, before its wider recognition, contributed to the development of women's issues as well as a disintegration of the historical gender equality the People's Poland had once claimed. Dealing with this legacy and the impact of women's removal from political power structures and other socio-economic realms in the early 1990s became a focal point for women-turned-activists in the face of discrimination and retrogression. 


\section{Abortion, The Church and Politics}

With the success of the Solidarity movement from a trade union to political revolution, Poland began its transition to the democratic, free-market state it is today. During that transitional time, there were a multitude of influences that shaped the political, social and economic restructuring which took place. Leadership in new political structures transitioned largely from communist government officials to their former adversaries, men who had participated and supported Solidarity and anti-communist resistance groups in the post-war period. These men were unified and motivated by a fierce dedication to Polish nationalism which was best exemplified by the instigation of political maneuvers which transformed society away from its recent communist legacy.

By prompting a public return to traditional Polish Catholic values and societal norms through political measures the new Polish government was able to accomplish several goals at once: Polish citizens could identify their national goals and characteristics as concerns of the state; clear, Polish leadership was established; and many abuses of the communist era were abolished. The legacy of these abuses as well as the more positive legal and social programs established during the communist era created a lasting competition between "secular modernity and Catholic traditionalism, with tensions displayed in both rhetorical and practical terms. ${ }^{, 54}$ As a newly independent country approaching the twenty-first century, Poland regarded the present as a time to strengthen and forge new relations with its international peers; the process of formulating the new Polish identity in these relations was to be determined by a combination of embracing historically Polish characteristics and values and also moving forward with necessary aspects of social, economic and political modernization.

\footnotetext{
${ }^{54}$ Joanna Z. Mishtal, “'Matters of Conscience': The Politics of Reproductive Healthcare in Poland," Medical Anthropology Quarterly 23 (2009), 162.
} 
Concerning women in this transitional period, the previous chapter has clearly established that though they were excluded from positions of political leadership, women and women's issues were often at the forefront of new political agendas and ideologies. Women's issues such as abortion, employment, social welfare, and more generally, women's role in society created controversy and caused tensions in the years surrounding 1989 and into the 1990s. Perhaps the most intense and widely recognized debate about the legitimacy of women's issues in Poland arises from the strong ties between the Catholic Church and Polish nationalism which had been unified for centuries against foreign occupation and rule. Numerous issues and debates have arisen in the context of anti-nationalist or anti-religious sentiments. ${ }^{55}$

In examining the Catholic Church's relationship with women, it is easy to see how debate has arisen. An external perception of the Church's views on women reveals a complicated stance and has been regarded by feminists as dichotomous, simultaneously idolizing women as mothers and wives while also suppressing their personal freedoms by reinforcing traditional, patriarchal structures within the family and society. The Church in Poland has long had a special influence over the population due to the homogeneity of Polish society with regards to the identification of the overwhelming majority as practicing Roman Catholics. ${ }^{56}$

Without question the Church had been a great support system for the anti-communist resistance, and in some particular ways, women. During the 1980s and throughout the communist era there were periods of economic or political crisis when the government failed to address the needs of women with regards to their families. At these times when the state was either unwilling or unable to provide for women and families, church-based welfare programs helped by providing traditional assistance in the form of food, sundries, clothing, emotional

\footnotetext{
${ }^{55}$ For further reading on Catholic nationalism in Poland after-1989 see: Mirella W. Eberts, "The Roman Catholic Church and Democracy in Poland," Europe-Asia Studies 50 (1998): 817-842.

${ }^{56}$ Hauser, Heyns and Mansbridge, 264.
} 
support and even household help. In these times and in many other instances, the Catholic Church has provided comfort, support and sanctuary for women and families over the years.

The Church's goals as a social and religious institution have never been to harm women and it would be unjust to insinuate such malicious intent. However, analyzing the policies, lifestyles and power structures promoted by the Catholic Church in Poland and around the world leads to a serious debate regarding women's issues such as employment, political rights and domestic relations - feminists and women's activists have questioned how and according to whom should women structure their lives?

While the Church encouraged and organized women's groups and clubs within the confines of Catholic social teachings, these associations were simply unfulfilling or not an option for many women who were deeply interested and invested in advancing women's equality, options and legal standing in society. ${ }^{57}$ Subsequently, new women's and feminist organizations were born of necessity to create public spaces where women could strategize and promote gender equality, its causes and issues. Many of these new groups were initially dedicated to fighting the seemingly imminent restrictions on women's reproductive rights (namely the ban on abortion); naturally they evolved into something more as women's oppression and changing conditions in Polish society developed during the following two decades. Inevitably many of these women's organizations were challenged and degraded by conservative, male political and Church leadership. ${ }^{58}$ Not until the late 1990s did any feminist organization or individual accomplish some relative success in creating dialogue and debate over women's issues.

Following the collapse of communism in Poland and the establishment of a democratic government, women were surprised to find legal rights and lifestyle choices they had previously

\footnotetext{
${ }^{57}$ Ibid, 265.

${ }^{58}$ Penn, 293.
} 
been assured by the state revoked and condemned so emphatically. In the early 1990s as political transition began, former Solidarity leaders and other Catholic policymakers pushed for national laws which reflected a more traditional and religious set of social norms and values. To women's advocates it seemed that this set of values disregarded Polish women's health and personal freedom as crucial policymaking concerns. Hanna Jankowska described women's confusion and responses to these measures in 1991 when the Unborn Child Protection Bill was introduced; she declared, "Many women still didn't realize what was going on," and furthermore, that for many women and men the thought of abolishing abortion was "absurd and stupid.",59

The reasons for the exclusion of women from political consideration in the early days of Polish democracy as well as the conservative, religious-backed movement behind the restrictive abortion law are complex. One must consider historical and cultural factors which played a tremendously influential role in Poland's transitional phase to democracy. These complex legacies created problems for women attempting to understand and participate in new governing structures which, in combination with other factors, has culminated in the criminalization of abortion, less focus on women's issues in the public discourse and the vilification of feminism in Poland. By examining the influence of the Catholic Church and Polish nationalism with regards to women's social and legal issues during the early 1990s it is possible to further analyze and understand women's situation in Poland over the past twenty years.

As mentioned, Poland is a country comprised overwhelmingly by citizens of the Roman Catholic faith, and therefore the assumption that Polish women would be morally opposed to abortion stands to reason. Interestingly, the passage of a 1956 law which legalized abortion and made such services safe and affordable for citizens was well received and subsequently utilized by many women. In his 1983 article reviewing Polish abortion statistics and history, Marek

\footnotetext{
${ }^{59}$ Hanna Jankowska, “Abortion, Church and Politics in Poland,” Feminist Review 39 (1991): 174.
} 
Okolski postulated that there "must exist a powerful countervailing force that motivates [Polish] women to seek abortions."

By examining the economic, political and cultural factors in Poland and in much of the Eastern Bloc during the communist era, it is easy to identify a number of reasons why women would be interested in limiting the size and scope of their family lives. With both parents resigned to working outside the home as a necessity during times of economic hardship, the availability and cost of childcare would certainly have been a primary issue of concern when considering parenthood. Equally as difficult to undertake would be further financial commitments required for raising children as well as the emotional considerations of being a working parent. Furthermore, some prospective parents may have had moral and political qualms about bringing children into a communist state which oppressed its citizens. These reasons could be considered precisely the 'countervailing force' which prescribed family planning for many women in communist Poland.

Though the statistics and data regarding abortion in Poland during the communist era are seriously flawed due to varying legal and financial arrangements surrounding the procedure, they do represent some of the medical activity and certainly the general trends surrounding women's reproductive choices at the time. Aside from medico-political concerns about reporting such data, Okolski notes that the statistics may be lacking simply due to the nature of the procedure and women's hesitation to provide information regarding their abortion histories. ${ }^{61}$ Moreover, Polish statistics indicate a rather steady and large number of abortions performed annually from 1960 to 1980.

\footnotetext{
${ }^{60}$ Marek Okolski, “Abortion and Contraception in Poland,” Studies in Family Planning 14 (1983): 266.

${ }^{61}$ Ibid, 264.
} 
The figures produced by Rocznik Statystyczny Obrony Zdrowia in Warsaw state that approximately 220,000 abortions occurred annually during the $1960-1980$ time period. ${ }^{62}$ These statistics reflect spontaneous abortions (miscarriages) as well as abortions performed in hospitals, private clinics and elsewhere carried out for both social and medical reasons. According to more reliable and statistically viable sources cited by Okolski, the "adjusted relevant number" of abortions annually during this period may be estimated at closer to $565,000 .{ }^{63}$ Demographer Andrzej Kulczycki assumes similar rates of abortion during the communist era, while also noting the uncertainty as to exact figures. Furthermore, Kulczycki comments on the wide-scale employment of abortion during the time:

If prior to 1990 there were close to 500,000 abortions per year, as generally assumed, this implies a ratio of about 75 induced abortions per 100 live births. This is three times greater than incidence levels observed in the United States, where levels are high relative to most other economically developed countries. ${ }^{64}$

In a state where legal abortion was quite obviously widely employed, the law had protected and improved the quality of life for many men, women and their families. Legalizing abortion "had extended the rights and personal freedoms of women; [had made] abortion safer, and had contributed to the elimination of criminal abortion, suicides by pregnant women, and infanticide, and had led to a decrease in the number of deaths following abortion." ${ }^{, 65}$ These positive consequences of legal abortion are frequently overlooked or dismissed when attempting to create a justification for anti-choice campaigns and legislation.

Women's activists have claimed that pro-woman, pro-choice policies have obvious benefits for families and children as well as for the women they affect directly. When women

\footnotetext{
${ }^{62}$ Ibid, 265.

${ }^{63}$ Ibid, 266.

${ }^{64}$ Andrzej Kulczycki, “Abortion Policy in Postcommunist Europe: The Conflict in Poland," Population and Development Review 21 (1995), 475.

${ }^{65}$ Okolski, 266.
} 
have more legal options for family planning they can be better suited to live healthy lives, make informed decisions, and be better prepared emotionally and financially when they do choose to have children. Disregarding the positive results of liberal abortion laws, critics attempt to undermine legal structures which benefit women's health and lives; in Poland there is and has been no greater critic of legal abortion than the Roman Catholic Church and its episcopate.

Interestingly enough there was and perhaps still is today some question over the extent of the Church's ability to influence its members' views regarding abortion. By examining attitudes of Catholic Poles and their adherence to religious dictates, the statistics show there is little objection to individuals dismissing edicts which conflict with their personal beliefs and behaviors, even as they continue to self-identify as practicing Roman Catholics in good standing. ${ }^{66}$ The view of abortion as infanticide and therefore an illegal criminal practice has consistently been a view that many Polish Catholics felt was extreme, or simply impractical. In a 1992 survey, only 11 percent of the polled population supported a full ban on abortion, some 22 percent supported strict restrictions on the procedure, while 35 percent thought that abortion should be legal with some restriction and a further 25 percent believed that abortion should be legal any time a woman requests the procedure. ${ }^{67}$ These statistics exemplify an interesting deviation from the alleged popular sentiment the government cited to justify the passing of the dramatically restrictive abortion law of 1993. How could these low levels of popular support for such a policy legitimize one of the most restrictive abortion laws passed in Europe only one year later?

Certainly, the Church's influence extends further than general public opinion; most notably it has a great deal of coercive power over political candidates themselves as well as the

\footnotetext{
${ }^{66}$ Małgorzata Fuszara, "Abortion and the Formation of the Public Sphere in Poland," in Gender Politics and PostCommunism, 243.

${ }^{67}$ Ibid, 243.
} 
media. The Church's legitimacy is complex, yet steadfast for a number of reasons, chief among them, the simple tenet that Church members must have faith and seek guidance from the Catholic episcopate and clergy as a social contract of their faith. Furthermore, following Poland's liberation from Nazi occupation during the Second World War and the establishment of the communist regime, the Church was stifled but not silenced as a leading voice in political discourse. Throughout Poland's communist era, the Church was "the only voice independent of the state and the spokesperson for national traditions and values professed by Poles themselves. ${ }^{, 68}$

Garnering additional respect as an institution which stood apart from the communist system and sustaining Poles at times when they required additional support established a strong sense of gratitude and perhaps even a sense of indebtedness on the part of those whom the Church assisted. Many of those receiving aid from the Church were staunch anti-communists, Solidarity leaders and future politicians of democratic Poland. As members of the Church and past recipients of its generous aid, many politicians had deep ties and a sense of obligation to protect and promote the Church's interests in the political realm. Fuszara bluntly stated that for these candidates who have a sense of debt and duty towards the Church, "It is difficult to oppose the church on an issue it finds so important. ${ }^{, 69}$

The overwhelmingly positive legacy for the Church, its affiliation with the Solidarity movement and leadership, put the Catholic episcopate in an ideal position to secure support for and advance its desired policies during the democratic transition of the early 1990s. Linking Solidarity with the Church and the Church with Polish nationalism was an emotional and effective tactic which was based in the historic context of struggle and support. Naturally, Polish

\footnotetext{
${ }^{68}$ Ibid, 249.

${ }^{69} \mathrm{Ibid}, 249$.
} 
patriotism was reaching its peak during Solidarity's victory over communism; national strength through unity allowed for these interconnected institutions of former anti-communist opposition to rebuff perceived fringe groups, such as women's advocates and feminists, denouncing them as un-patriotic, un-Christian and therefore detrimental to national progress. In this political climate, the Catholic Church pressured new democratic government officials to re-instate Catholic teachings in schools, restrict and eventually eliminate the availability of abortion, de-emphasize the use of contraception for women, and influence society in a more ideal Catholic, Polish state.

The year of 1993 brought a new, exceptionally restrictive abortion law to Poland and marked a significant political victory for anti-abortion advocates; the Act on Family Planning, Human Embryo Protection and Conditions for Legal Pregnancy Termination was passed in January of that year. Legislative and public debate surrounding the law's proposition was described as being "marked by hyperbole and an absence of compromise."70 Opponents made the typical, logical arguments regarding the debate over when life begins, the slippery slope of criminalizing all types of contraceptives, the issue of Church-state involvement boundaries, women's health issues and the danger of back-alley practices, and finally the overarching moral and ethical issues involving abortion.

Shaped by the strong traditional, national and religious trends in Polish political leadership at the time, the abortion debate took its defining form at the ethical and moral level. Restriction proponents argued a bold and powerful line, stating, "The sanctity of life was to be defended, therefore, because of the biblical exhortation not to kill, Catholic social teachings on the family, the tragic experiences of Poland's disastrous losses under Nazism and Stalinism, and

\footnotetext{
${ }^{70}$ Andrzej Kulczycki, “Abortion Policy in Postcommunist Europe: The Conflict in Poland,” Population and Development Rule 21 (1995): 485.
} 
its selection as the main sight for executing Hitler's design for the Holocaust."71 This type of protectionist and traditionally paternalistic argument was to a certain extent well-received among legislators, though it was blatantly rejected by opponents of the law and of abortion restrictions as well as by a large proportion of the general population.

As an alleged compromise, the law itself made three exceptions allowing the legal termination of pregnancy: if the pregnancy signified a serious threat to the woman's life or health, if the pregnancy was marked by a "severe, irreversible damage to the fetus or an incurable, life-threatening disease affecting the fetus," and if the pregnancy was the result of a criminal act. ${ }^{72}$ To abortion-rights advocates this 'compromise' was nothing short of a joke, while the Episcopate was disappointed that three provisions were included at all, having favored a total ban but acknowledging that public opinion could not be swayed to such extremes. ${ }^{73}$ Regardless of the potential and quality of the debate, the matter was settled within the government as the law was passed and put into effect.

The history, debate and laws regarding abortion in Poland have been extremely volatile in both society and politics during the democratic transition and in its wake. Coming to terms with the influences of traditional political structures built upon patriarchal formulas and male leadership at the cost of continually excluding women from the public political sphere has been denied by some and deemed appropriate by others, including the 'new feminist' movement of Catholic women. Some western feminists have derided their Polish counterparts for what they view as a lack of determination in promoting women's issues (equal rights, access to abortion, personal safety and individual freedoms) which has resulted in a lack of progress towards gender

\footnotetext{
${ }^{71}$ Ibid, 486.

${ }^{72}$ Françoise Girard and Wanda Nowicka, "Clear and Compelling Evidence: The Polish Tribunal on Abortion Rights," Reproductive Health Matters 10 (2002), 23.

${ }^{73}$ Mishtal, 170.
} 
equality. Such criticism is short-sighted and culturally insensitive: it disregards as well the historic context which has created the modern Polish woman and her place in society and fails to recognize the lengthy struggle which will precede significant improvement in women's issues and gender equality in Poland.

Many Polish women began protesting the 1993 abortion law even before its passage and have continued to do so ever since. In 1996 the 1993 law was "briefly liberalised by the left-wing Parliament... [Though] abortion was once again restricted in 1997 when the Polish

Constitutional Court declared the liberalised Act unconstitutional."74 Throughout the 1990s there were many other examples of popular demonstrations and grass-roots protests against the abortion law; however none were successful in forcing changes to the legal system or creating enough political pressure to spark an overturn of the law.

One of the largest demonstrations against the law was staged in 2001 when the Polish Federation for Women and Family Planning hosted a "Tribunal on Abortion Rights" in Warsaw. The tribunal was structured to present the cases of seven women relating their experiences struggling to obtain abortions in Poland. These cases were presented to a panel of both international and Polish "judges" and the press was invited to hear the testimony. After hearing the testimony of these seven women, "the judges noted that because the Anti-Abortion Act is not being enforced to allow women to have abortions to which they are entitled, both the law and the medical profession are being discredited."75 Further conclusions regarding the irresponsibility of additional illegal restrictions imposed upon women's access to abortion and violations of human rights in reproductive health care were made public, along with the women's testimony about their experiences. Occurring just two months prior to a national election, the Tribunal attempted

\footnotetext{
${ }^{74}$ Girard and Nowicka, 23.

${ }^{75}$ Ibid, 27.
} 
to bring abortion and women's reproductive health care back to the forefront of political consideration and succeeded. The following year, “International Women's Day... was devoted entirely to the theme of reproductive rights...The main slogan was: 'Yes to contraception, yes to sex education, yes to legal abortion." ${ }^{, 76}$ This direct challenge to Church-backed legislation and educational programs signifies progress in the boldness of the women's movement, in its willingness and ability to publicize previously intolerable positions.

Most recently in the abortion-rights debate in Poland, the European Court of Human Rights has reviewed a case which could have tremendous importance for the future of Polish abortion regulations. On May 26, 2011, the court ruled that "Poland violated a woman's human rights when she was repeatedly denied a prenatal genetic examination after a doctor discovered fetal irregularities during a sonogram." ${ }^{, 77}$ The woman involved with the case, R.R., was within the current Polish legal restrictions to request further testing, and should have been permitted a legal abortion when genetic testing provided proof of fetal abnormalities and deformities. Due to the refusal of multiple doctors to perform this testing, the delay in establishing R.R.'s fetal impairment resulted in her pregnancy surpassing the time limit for a legal abortion.

The court's ruling of human rights violations in Poland could potentially have a significant impact on women's reproductive health. Recognizing past violations and continued mistreatment of women in violation of the law is a victory for women's health advocates. This ruling will serve as a warning to healthcare providers and governmental agencies that human rights violations and personal ideologies have no place in reproductive health care in Poland. President of the Center for Reproductive Rights, Nancy Northup has praised the court's decision

\footnotetext{
${ }^{76}$ Ibid, 28-29.

77 "European Court Issues Landmark Decision Against Poland, Says Woman Entitled to Prenatal Genetic Testing," in The Guardian (Online Edition, 26 May 2011), http://reproductiverights.org/en/press-room/european-court-issueslandmark-decision-against-poland-says-woman-entitled-to-prenatal-ge . Access date 15 June 2011.
} 
stating, "The court has recognized that withholding information or lawful health services from a woman deprives her of the ability to make extremely important and private decisions about her own life. ${ }^{.78}$

Though the court's ruling which censured Poland's lack of determination to ensure its citizens' rights may not have been as harsh as some advocates would have liked, it is nonetheless a progressive attempt at working towards a more effective, safe and just healthcare system for women. What the court ruling really does is establish the necessity of Polish authorities to respect their nation's current laws and the rights of its citizens; more specifically, in this case the court has reminded Poland that abortion and genetic testing are procedures which are considered necessary and legal in some cases. Women's rights activists can use decisions such as 'R.R. v. Poland' to maintain the current accessibility of abortion procedures while attempting to further reduce the restrictions on reproductive healthcare procedures more generally.

As the many positive aspects of abortion are frequently overlooked and often rejected by conservative, religious and patriarchal institutions, Polish feminists and women's issues groups will need to invent new ways in which to argue the logical and beneficial consequences of liberal abortion laws. The potential, future overturn of current restrictive abortion laws in Poland would create a more pro-woman climate from a feminist perspective and would advance women's issues and choices to the forefront of Polish socio-political concerns in some circles. Furthermore, advancing women's issues and reducing restrictions on abortion laws will benefit society at large by creating a more egalitarian national community where through choice and personal freedoms, men and women will be able to make the best actions for themselves and their families. Less-restrictive abortion laws have the potential to enhance individuals' lives by reducing economic burdens and emotional stress related to family planning. Polish women, men

\footnotetext{
78 "European Court Issues..."
} 
and families will benefit from feminist activism not only in this healthcare and family issue, but in the larger spheres of labor, political, social and educational activities. 


\section{Women's Activism and The Concept of Feminism}

The emergence, and in some cases lack of emergence, of women's and feminist issues in Central and Eastern Europe has posed many questions since 1989. The political backlash against these issues (namely the exclusion of women from political leadership and legislative proceedings) during democratic transitions has been described as the root of a continued "allergy" to feminism in Poland and throughout the region well into the twenty-first century. ${ }^{79}$ Critics have cited issues with feminism as a foreign concept imported from western societies, reasoning that such non-native ideology is conflicting and even harmful to local culture and traditions. As previously discussed, the Polish case has pitted feminism against nationalism in the context of anti-Catholic, anti-Polish tradition of both cultural modernization and its associations with socialist principles. It is in this context that feminism is most often understood in the Central East European region - as a divisive and unnecessary movement which opposes nationalism, unity and historic tradition. Realistically, the debate over feminism as an imported rather than native phenomenon will never be settled. Undoubtedly, many Polish feminists acknowledge the influence of western feminism while also proclaiming their own personal, local foundations. Since 1989, the anti-feminist sentiment has appeared to be winning the public debate in Poland. By 1995 Ewa Hauser had already written describing the "return to a repressive patriarchal 'gender regime' ...in the making in Poland." 80

\footnotetext{
${ }^{79}$ For further reading and a more specific discussion of post-1989 anti-feminist backlash, see Barbara Einhorn, Cinderella Goes to Market: Citizenship, Gender and Women's Movements in East Central Europe (New York, 1993), 182-215 and Nanette Funk and Magda Mueller, Gender Politics and Post-Communism: Reflections from Eastern Europe and the Former Soviet Union (New York, 1993), 1-14, 257-273.

${ }^{80}$ Ewa Hauser, "Traditions of Patriotism, Questions of Gender: The Case of Poland" in Post-communism and the Body Politic ed. Ellen E. Berry (New York, 1995). The patriarchal gender regime Hauser describes is tied heavily to the Catholic Church and traditions from the pre-communist era which continue to define Polish society even in the midst of modernization. For further reading on patriarchal political and societal traditions, see Barbara Łobodzińska Family, Women and Employment in Central-Eastern Europe (Westport, 1995), 193-203 and Renne, 34-41 as well as the introductory chapter of this work.
} 
Just as Poland had struggled as a state, Polish women had struggled with who they were and what they could do. Anna Reading described the interesting parallels between the state and its women, "Poland's historical struggle for identity as a nation state bears striking resemblances to women's struggle for identity, as outlined by Western feminists. For example, Poland was partitioned; women are partitioned and annexed by the workplace, by children, by men." 81 As Polish women continued to deal with these challenges, some extended their commitments further to fight oppressive laws and societal restrictions which threatened their choices and lifestyles. The following will discuss the issue and history of feminism, engagement with Western feminists, modern Polish activism and women's political activity since Solidarity.

The acceptance of feminism is a relatively recent addition to social philosophy and political movements having only made its modern roots in the political struggles for suffrage in Europe and North America during the nineteenth and twentieth centuries. First and foremost, it is necessary to describe the core tenets of feminism and to establish the goals of the movement. Most feminist organizations and individuals consider equality to be the core principle and goal of feminism. Recognizing the imbalance of political and domestic power, the disproportionate representation of men over women and the perpetuation of these conditions leads feminists to seek ways in which to resolve these discrepancies in a more egalitarian manner. Dr. Aneta Gawkowska, a scholar who has written on such issues as Polish women and employment in the Postcommunist era, concurs that the key concept of Polish feminism is equality or freedom from oppression. Furthermore, there were no separate waves or stages of feminism in Poland, as the movement came into being largely at one time during the latter half of the twentieth century. ${ }^{82}$

\footnotetext{
${ }^{81}$ Anna Reading, Polish Women, Solidarity and Feminism (New York: Macmillan, 1992), 19.

${ }^{82}$ Abigail Miller, "Interview with Dr. Aneta Gawkowska," Warsaw, Poland . 6 December 2011.
} 
The modern historical legacy of feminism is contentious and complicated. Of course, there has always been a strong distaste for feminist principles by more conservative and religious factions of society - two groups which have sizable populations in the Central and East European region. Misconceptions regarding feminists' alleged desire to elevate the status of women over men have contributed greatly to developing and sustaining anti-feminist sentiment. Furthermore, it conjures abstract visions of communist conspiracy, misandrist persecutions and even homosexuality, or other equally negative products of cultural modernity - the general perception being that feminism seeks to destroy and make difficult men's lives in an unnatural way. This perception includes theories that feminism will promote women's agendas and opportunities over men's, will falsely persecute men for discrimination and sexual harassment, and will replace men as political and family leaders thus emasculating them and rendering men obsolete.

This perception, in turn, creates a political atmosphere in which male leaders are compelled to suppress such movements and stifle attempts to seriously consider women's issues as important factors to society at large. Aneta Gawkowska has also described the primary obstacles to Polish feminism today: first, that Catholic culture, family ties and community orientation are more important and ingrained into the Polish psyche than individual concerns such as women's issues and "selfish" feminism; second, that Polish women and feminists as well may not identify or agree with the new queer rights/homosexual agenda for which Western feminism now advocates. ${ }^{83}$

Though these issues and ideological differences have been cultivated in both the long and short term, there were plenty of reasons as to why feminist women's activism developed in Poland. Looking back, Poland in particular during the early twentieth century and into the

\footnotetext{
${ }^{83}$ Miller, ibid.
} 
communist period had an interesting divide between two feminist groups; 'socialist feminist' groups (which later found state support) and the contingency of 'bourgeois feminism' of the intelligentsia and upper echelons of society ${ }^{84}$ The women who identified with a shared sense of feminist principles (gender equality, anti-discrimination, etc.) had difficulty agreeing upon the basis of access which women required to attain equality with their male counterparts. Bourgeois feminists believed that political access to the democratic process would bring about women's equality while their socialist feminist sisters believed the issue was more related to the power of private property, equal pay, etc.; in the view of the latter, under the communist system Poland's women had already been given and guarantees of their equality with men. ${ }^{85}$

Of course, the perception and reality of women's lives is at the core of any feminist belief system. In communist Poland, the state socialist propaganda promoted the 'reality' of gender equality, though that myth has been thoroughly challenged and debunked by feminist scholars. Simone de Beauvoir, Barbara Einhorn, Małgorzata Fuszara and Angela Coyle have all denied the idyllic picture of women's equality in communist Eastern Europe by describing women's 'double burden' of embracing their roles as mothers and workers. Interestingly, these same scholars regard the state provisions and rights for women regarding employment, benefits, childcare, contraception and abortion as typical issues which Western feminists campaign for. ${ }^{86}$ The complex legacy of this socialist welfare system benefited women in many ways and contributed to a sense of half-hearted, half-realized feminist principles during the communist period. It is extremely complicated to negotiate this legacy in historical remembrance as well as in the development and continuity of feminism in the region.

\footnotetext{
${ }^{84}$ Kristen Ghodsee, "Feminism-by-Design: Emerging Capitalisms, Cultural Feminism, and Women's Nongovernmental Organizations in Postsocialist Eastern Europe," Signs 29 (2004): 732.

${ }^{85}$ Ghodsee, ibid, 732.

${ }^{86}$ Angela Coyle, "Fragmented Feminisms: Women's Organisations and Citizenship in 'Transition' Poland," Gender and Development 11 (2003): 59.
} 
Without question from 1989 and continuing through much of the 1990s, women's position and possibilities in Polish society seemed to become increasingly limited. Ewa Gontarczyk-Wesola described the deteriorating climate for women, noting the increasing unemployment in female demographics, the decline in women's political activity at all levels, the social policies encouraging women to remove themselves from the public sphere while returning to traditional family roles and the criminalization of abortion in less than one decade of democratic reform. The same type of problems, especially employment, plagued East German women after their national revolution which resulted in the reunification of East and West Germany; “East German women's higher and longer unemployment has often been offered as evidence that they are the 'losers of the reunification process.',"87

Returning to Poland, Gontarczyk-Wesola went so far as to declare, "Despite recent political and economic changes in Poland, women's situation seems to be static, if not deteriorating." ${ }^{88}$ Gontarczyk-Wesola attributed the disregard of respect and concern for women's issues to the public lack of knowledge regarding women's contributions to society, particularly during the Solidarity movement. This connection is one of the most insightful conclusions regarding the dismissal of women's issues in a larger sense. Societies are quick to dismiss feminist and pro-woman agendas as superfluous due to the lack of publicity, social tradition or national causes necessitating them. Solidarity men and Polish society also viewed women's issues as divisive within the cause. It has been argued that Solidarity's program was too important to be jeopardized by such leftist, radical women's issues which may have created rifts within the organizational structure and undermined its larger goals.

\footnotetext{
${ }^{87}$ Rosenfeld, Trappe and Gornick, ibid, 113.

${ }^{88}$ Ewa Gontarczyk-Wesola, "Women's Situation in the Process of Change in Poland," in Ana's Land, 40.
} 
This is perhaps the most pertinent event to Polish women's self-definition in recent history: the legacy of women's involvement with the Solidarity movement and the failure of this involvement to translate into recognition and gender equality in post-communist Poland. As discussed earlier, it was this systematic process of excluding women from planning, leadership transition roles, and government and policy-making groups as Poland became a democratic state that has had a vast and deep impact on the lives of women. More than just the fight over abortion, women in Poland were affected by the traditional, conservative and Catholic sensibilities of the new order which directed their place in the workforce, the home and in society.

In the wake of Solidarity's failed legacy for gender equality, women found new ways and causes to take up as their own and this was the time when women's activism and Polish feminism began to develop in its own right. During the 1990s and 2000s groups protesting the restrictive abortion law, wage and opportunity inequalities in the workplace, domestic violence and trafficking of women and many other forms of gender discrimination were born in the wake of Poland's transition to democracy. Though there had always been a small faction of Polish feminists, greater numbers of women came out and began building feminist organizations.

Prior to the 1993 law restricting women's access to abortion, it was significantly more difficult for groups centered on women's issues to establish themselves and enter public debates legitimately, though some did exist. The passage of the 1993 anti-abortion law, which assaulted women's reproductive rights, their lives and their welfare proved an opportunity to enter into the public sphere with ample justification: the Movement for Women's Self-Defense, the 
Association for the Dignity of Women, the Feminist Association, and Pro Femina were created in the wake of the new abortion law in $1993 .{ }^{89}$

Aside from the abortion law, feminists and women's activists had and have plenty to fight against and work for. In the early 1990s Polish women (like their German sisters) consistently experienced higher rates and longer durations of unemployment - by late 1993 women's unemployment reached $56 \%{ }^{90}$

As discussed earlier, with the creation of such groups and the ensuing public debate on all levels of Polish society, and even internationally, the abortion law in Poland has been and will continue to be tested by its opponents. In 2001, pro-choice women's advocates presented the International Tribunal on Abortion in Warsaw. The tribunal made further conclusions regarding negative effects of the anti-abortion laws by taking the "opportunity to bring to the attention of a wider public the personal tragedies of women who had been adversely affected by the Act."91 After the Tribunal, women's day celebrations, other protests against the law and attempts to instigate change have taken the form of marches, demonstrations, petitions and campaigns to promote awareness of women's reproductive health and social issues. Most recently, Gazeta Wyborcza has reported on the imminent draft of a new law which will be presented to health minister Marek Balicki proposing legal abortions up to the twelfth week of a woman's pregnancy as well as to overturn restrictions against in-vitro fertilization. ${ }^{92}$

As the anti-abortion law created a cause for women's activism, it also marked the beginning phase of organizational initiatives. Statistics show that initial organization happened quickly and "by 1993, there were 59 officially registered women's organizations in Poland, and

\footnotetext{
${ }^{89}$ Ibid, 251.

${ }^{90}$ Bozena Leven. “Unemployment Among Polish Women,” Comparative Economic Studies 35(1993):136.

${ }^{91}$ Girard and Nowicka, 24.

92 “SLD: Czas na aborcję," Gazeta Wyborcza, February 19, 2011, Online Edition, http://wyborcza.pl/1, 75478,8532532,SLD_na_aborcje.html.
} 
the number rose to 70 by 1995 . In 2000 , there were about 150 registered women's organizations. ${ }^{.93}$ If these organizations were just beginning, developing their identities, and attempting to recruit support, they found difficulty in each task. Women's studies scholar Jill Bystydzienski noted the travails these women's organizations experienced, "Despite a more favorable climate for the development of feminist organizations, however, activists found many obstacles to effective action." ${ }^{" 94}$ These obstacles chiefly included feminists' perceived allegiance with leftist or communist ideology and an opposition to popular, Polish and Catholic values.

Other scholars have attempted to classify these early women's issues and feminist groups. It seems that women's groups in Poland had three distinctive features: most were relatively small, diverse, often focused on singular purposes, and eager to engage with one another. ${ }^{95}$ It may also be said that these groups and Polish feminism at large have had the common feature of finding difficulty in relating their identities to the public and setting specific goals. This problem of identity has always created complex organizational and methodological difficulties for the Polish feminist movement.

Among these small groups, some had a tradition of activism during Poland's communist period such as the Polish Feminist Association, and others like Pro Femina arose from specific points of contention such as the threat to women's reproductive choice. ${ }^{96}$ Though many of these organizations were focused on single issues, the high-profile nature of their battles against restrictive abortion laws and the trafficking of women and girls did help draw in considerable support from IGOs and NGOs. Unfortunately, throughout the 1990s these battles, high-profile or not, were unable to reach the audience of Poland's political leadership. These women activists,

\footnotetext{
${ }^{93}$ Jill M. Bystydzienski, “The Feminist Movement in Poland: Why So Slow?” Women's Studies International Forum 24 (2001), 506.

${ }^{94}$ Ibid, 506.

${ }^{95}$ For further reading see: Olson, Einhorn, Coyle, Ghodsee, ibid.

${ }^{96}$ Einhorn, 191-192.
} 
sometimes working for a greater feminist cause, sometimes working simply to promote one step towards gender equality, took on long volunteer work hours on top of their other responsibilities (family, home, education, work), not to mention public taunts, and were simply ignored by the government in many instances. For example, "One million people signed a pro-choice petition that feminists presented to the Sejm in 1991, but this, like all other tactics, failed to turn the tide. ${ }^{97}$

Aside from activism, addressing women's issues in Polish society and Central and Eastern Europe as well as throughout the world has become a major topic in academic scholarship over the past twenty to thirty years. While bringing increased awareness and stimulating intelligent debate over these issues is tremendously important, Western feminist scholarship has had both positive and negative ramifications on the progress of women's movements. In the positive sense, feminist scholarship has helped to identify specific causes and origins of anti-woman policies and problem areas in society. It has also identified perpetrators of such discriminatory policies and has noted apparent discrepancies between polls of public opinion and state-promoted policy. Understanding the disconnect between practical, public opinion and government legislation will be an important tool in reversing restrictive policies regarding women's reproductive rights and encouraging new, woman-positive agendas.

One of the most notable scholarly debates arises between the schools of gender analysis and Marxist thought. Gender historians have often been criticized by their Marxist counterparts as unnecessarily specialized and dismissive of the core problem of class and economic power. Although they do disagree as to particular aspects of subject matter worthy of their analysis, and to a certain extent methodology, gender and Marxist scholar/activists conduct similar work and pursue common goals of equality. Unfortunately, for the time being these schools of thought

\footnotetext{
${ }^{97}$ Penn, Solidarity's Secret, 282.
} 
remain entrenched in disagreement. Scholar Almira Ousmanova has examined the situation of gender and cultural studies in Eastern Europe, pursuing an explanation that views gender studies as inherently foreign and opposed to Marxist traditions:

East European Feminism in general has been traumatized by its long-term subjugation to the political and theoretical stakes of Marxism, beginning in the early $20^{\text {th }}$ century when the Russian women's movement was absorbed by Bolshevism. For the latter and for Marxism in general the relationship between the sexes was considered a primary one, determined by the natural division of labour and, therefore as pre- and non-political; the discrimination of women was regarded as an index of social inequality as such; similarly, the solution of the 'Woman's Question' had to reflect the global process of emancipation of all subalterns... That is why feminists rise in opposition against the 'class universalism' of Marxist social analysis. ${ }^{98}$

Ousmanova's work enlightens the reader as to just how pervasive the Marxist school of thought can be in Eastern Europe; it continues to affect the majority of political and social analyses in both the academic and public spheres of Eastern Europe. The foreignness and contradictory nature of gender and culture studies challenge the long-standing paradigms of thought in post-Soviet Eastern Europe. In reading Ousmanova's article - though it does not specifically discuss the case of Poland's women and Solidarity's legacy - the common themes of the region regarding feminism, gender and culture studies as well as Marxism become clearer to the reader. Placing the school of gender studies and history into the Marxist context provides a deeper understanding of the causes behind anti-feminist sentiment in the region as well as the larger issue of the Marxist/gender studies debate.

If many scholars have pointed to the legacy of Marxist ideology in Central and Eastern Europe as constantly redirecting women's issues to the broader category of class and economic stratification; a major trend in thought was that a gendered analysis of societal problems would ultimately undermine effective coalitions built upon economic determinants. ${ }^{99}$ Furthermore, the

\footnotetext{
${ }^{98}$ Almira Ousmanova, "On the Ruins of Orthodox Marxism: Gender and Cultural Studies in Eastern Europe," Studies in East European Thought 55 (2003): 38.

${ }^{99}$ Ghodsee, 735.
} 
continued historical legacy of competing ideologies (liberalism v. conservatism, federalism v. nationalism, and communism v. capitalism) in Central and Eastern Europe have been divisive and detrimental to feminism and societal issues more generally. For the second half of the twentieth century as the Cold War raged, Central and Eastern Europe became the cultural, political and economic battlefield between the United States and the Soviet Union as solutions to societal problems fractured along ideological lines.

Another point of contention is the negative reception of some Western feminist activists and scholars with regards to Polish progress in the promotion and protection of women's issues. Western feminist scholarship has also been somewhat detrimental in its alienating and critical views regarding Polish women's responsibility for their current situation, at times blaming women for not doing more, pressing harder or otherwise somehow preventing negative policies and societal norms from being established. Now, in addition to alienating potential Polish feminist allies on the basis of labels alone, some Western feminists have created further hesitation toward and even derision of women's causes by emphasizing blame of past shortcomings, most notably the inability of the Polish feminist movement to block the abortion ban legislation, rather than focusing on current activism and what may be done in the future to encourage positive change for society.

All things considered, women's rights, feminism, the legacy of Solidarity and the current state of women in Poland comprise a vast and complex issue for scholars, activists and citizens to deal with. By incorporating historical knowledge and analytical assessments of influential institutions and policy it is possible to understand the current situation and to make conclusions about how women in Poland interpret and react to their assigned roles politically, economically 
and socially. Examining Polish women's responses to specific policies and further analysis of feminist organizations and goals within Poland over the last decade will provide further insight.

In the late 1980s and early 1990s as the Iron Curtain fell many countries in Central and Eastern Europe began to make the political transition to democracy and the economic transition to capitalism with many spectators and supporters. Naturally, these political and economic processes called for Western assistance and planning and so, many Western European and American groups rushed into the area to provide support. As these transitions took place, governments and NGOs around the world observed problems and proposed solutions - including many issues concerning women. In hindsight, many feminist scholars recalled women's worsening conditions in the wake of the region's democratization. In Central and Eastern Europe, according to Frances Olsen's account from 1997:

Unemployment is...especially high among women. Discrimination against women has increased as governments have failed to enforce existing anti-discrimination provisions and some conservative and nationalist regimes have even promoted discriminatory policies to limit women's roles. The transition to a market economy has precipitated a decline in social and public services, including sharp decreases in the availability of child care facilities. Sexual abuse and domestic violence appear to be increasing, and little is being done to stop them. Reproductive freedom has become a serious issue...Prostitution is on the rise, and the working conditions of women and girls in prostitution are especially harsh and dangerous. ${ }^{100}$

With such a precarious situation for women in the region, much attention was paid to it by Western feminists and governments alike. As observers and organizations made their way into Poland to direct attention and attempt to mitigate these unacceptable situations for women, the issues of cultural misunderstanding and patronizing attitudes on the part of Western feminists towards Polish women became apparent. Olsen and many other scholars have noted a common sentiment arising from the former Soviet-dominated countries, "To the extent that Westerners

\footnotetext{
${ }^{100}$ Frances Elizabeth Olsen, "Feminism in Central and Eastern Europe: Risks and Possibilities of American Engagement," The Yale Law Journal 106 (1997): 2217.
} 
view Central and Eastern Europe as Other, it is argued, they will never understand the region or be able to help its people."101

Though it may not be exactly correct to classify revisionist history and challenges to Western views of Central and Eastern Europe as postcolonial, the core principles are the same. Scholars such as Kristen Ghodsee have embraced the idea of "revision or rejection of previous historical accounts" including the revision of essentialist representations, pejorative connotations and binary opposition in our modern historiography as they work on a multitude of subjects in many regions around the world. ${ }^{102}$ There is no doubt that the school of postcolonialism has had a tremendous influence on gender and history, especially the process by which Western feminists go about assisting their sisters in different cultural traditions. During modern Polish feminism's struggle to develop throughout the 1990s, many scholars and activists echoed these sentiments of frustration with the West's criticism and inability to understand the significance of different socio-political conditions which shaped their reality.

Ghodsee critiques the many forms of Western cultural, intellectual, political, and economic imperialism by noting the limited success of many such projects in the Central and East European region, particularly in the field of women's issues and feminist agendas. Ghodsee suggests revision to the process by which new projects are introduced for Central and East European improvements:

Projects to address the needs of women may need to include politically 'dangerous' strategies to help women decide for which 'needs' they will work and for which 'rights' they will fight. Only then will international efforts to raise the living standards of women in Central and Eastern Europe be both sensitive to the social and political history of the region and relevant to the daily struggles of women living through a most tumultuous period of economic transformation. ${ }^{103}$

\footnotetext{
101 Ibid, 2222.

${ }^{102}$ Green and Troup, ibid, 278-280. .

${ }^{103}$ Kristen Ghodsee, "If the Shoe Doesn't Fit? (Wear it Anyway): Economic Transformation and Western Paradigms of Women in Development Programs in Post-Communist Central and Eastern Europe," Women's Studies Quarterly 31 (2003): 32 .
} 
Obviously the development and influence of postcolonial and subaltern studies has had a beneficial impact on the thinking and action of scholars and activists committed to a more accurate representation of the past, particularly in the fields of gender studies and history. Simply by the recognition of power dynamics in history and historiography, activists and scholars alike can benefit from revising their understanding of the past and considering new ways in which the future might be shaped.

The principles of the cultural feminism which precipitate these issues are, of course, not problems limited to intervention in the Central and East European (CEE) region. There exists to this day much debate and discussion among feminists as to whether or not there is a supreme meta-narrative of women's experiences which establishes their common needs, ideals, behavior and desires - thus bonding all women together across lines of class, culture, race and religion. The general perception of late has acknowledged that this is probably not the case, though some dissent can be heard. Although this debate continues, feminists have become more aware of cultural and historically significant traditions which affect women differently across the world. Engagement with Western feminists as well as sisters across the world can and will prove beneficial for women in CEE and all parties involved. Increasing the working power of the movement and encouraging shared ideas and collaboration on initiatives will foster improved relations and understanding among women who do share some common goals and values, and ultimately who all work to improve the world and promote gender equality - no matter the differences in their respective creeds.

Reviewing the multitude of types, sizes, goals and tactics of women's organizations in the 1990s, it comes as no surprise that in the wake of the anti-abortion bill there were many changes and upheavals to feminist and women's activism in Poland. Some women's 
organizations fractured and disbanded, but others were enthused by the passing of the abortion law which they viewed as a sort of 'throwing of the gauntlet' and a serious threat to women's lives and choices which they must challenge. Małgorzata Fuszara argues that, in fact, "in the longer term, the anti-abortion campaign may have shot itself in the foot: 'Mobilization of the Polish women's movement seems to me to be the outstanding achievement of the parliamentary campaign to ban abortion."

One of the longest lasting and most public demonstrations of women's activism continues to the present, the Warsaw Manifa. Women from all regions of Poland gather each year for a large demonstration and march in Warsaw in the spring to protest against the "exploitation of women, lack of justice and [to promote] the right to human dignity in ordinary schools and supermarkets, universities and hospitals." ${ }^{105}$ This march begins at the Palace of Culture and Science and ends at the Sejm where this year over 6,000 women, men, transgender and gay people participated in this "colorful and happy" protest which hoped to promote the idea that "every revolution starts with a change of consciousness.",106

As for other forms of women's activism, in the early millennial years it was estimated that there were some 200 active women's groups and organizations in Poland. Interestingly there is a divide between these groups - some are genuine feminist and women's issues groups while others are merely re-workings of Catholic, pro-family groups which purport to advocate for women but actually promote conservative and traditional roles for women. ${ }^{107}$

In the summer of 1999, Agnieszka Graff produced a feminist manifesto which succeeded in drawing attention to women's and human rights in Poland and caused quite a controversy,

\footnotetext{
${ }^{104}$ Małgorzata Fuszara, "Legal Regulation of Abortion in Poland," Signs 17 (1991): 128.

${ }^{105}$ Elizabeth Korolczuk, "Warsaw Manifa 2011,” http://www.manifa.org, 15 April 2011.

106 Korolczuk, ibid.

${ }^{107}$ Coyle, 60.
} 
since no feminist or gender critique of Polish politics had been so successfully publicized. Graff's piece was published in the popular newspaper Gazeta Wyborcza and drew attention to the Polish conservatives' rejection of women's issues as part of human issues, which Graff considered absurd and frustrating considering Poland had ratified many human rights treaties. ${ }^{108}$

Feminism experienced growth in both these types of individual activism and in organizational proliferation. In fact, the anti-abortion legislation and debate produced an estimated thirty or so women's protest organizations during the 1990s. ${ }^{109}$ However noteworthy these new organizations were, it is also important to clarify that much feminist activism and public outcry was conducted on an individual basis, like Graff's manifesto. Letters to newspapers and politicians, support for women's shelters and family planning funds, and discussions with family, neighbors and friends were and remain ways in which Polish women contributed every day to heightening awareness of women's issues and feminist causes.

Conversely, since its inception, the concept of feminism has also been disturbing and problematic for many people. Recognizing and understanding the importance of dismantling patriarchal structures and oppression of women is controversial in that it forces people to admit that there are inequality and prejudice on the most basic levels of societal foundations in the homes, schools, workplaces and houses of worship of all citizens. In Central and Eastern Europe the issue has been particularly contentious due to the strong national ties of the population to the Catholic Church and the lack of a strong historical legacy of women's movements during the early twentieth century.

Even in the twenty-first century, the feminist movement has not been accepted by many people, especially in the Central and Eastern European region. Kristen Ghodsee argues, "feminist

\footnotetext{
${ }^{108}$ Penn, 293-294.

${ }^{109}$ Hauser, Heyns, and Mansbridge, 258.
} 
is still a bad word and there is still an atmosphere of antifeminism," and what feminism that does exist in the region "looks to find solutions for how the worst offenses of patriarchy can be mitigated, while never challenging the social or economic relations within which patriarchy thrives. ${ }^{\prime 10}$ Feminists must and will continue to further challenge these structures in Poland, throughout the region and across the world. Continued support from IGOs and NGOs will encourage the spread of feminist values and gender equality until global society accepts them as universal.

\footnotetext{
${ }^{110}$ Ghodsee, 728.
} 


\section{Current Issues: Problems and Potential for Women}

Where do Polish women's activists and feminists stand today? After two decades of development since the fall of communism it seems that Polish women's organizations of all types are thriving. Public debates over reproductive rights, sexuality, discrimination, violence and other issues typically described as "women's" issues have assured the continued presence of women's advocacy groups in Poland and create potential for progress towards greater levels of gender equality in society.

Of the many problems facing Polish society, there has been no shortage of public criticism, academic scholarship and visible demonstration made by feminist and women's groups. Though Polish feminists have always had a problem defining their specific goals and parameters in activist organizations, it seems somewhat obvious that modern Polish feminism has come to embrace gender equality as its core principle while acting on the issues which it believes have the most significance and potential for improving the lives of Polish women. Unfortunately, there is no shortage of issues which require attention. Furthermore, the complexity and widespread nature of these problems will necessitate many years of work and lobbying on behalf of feminists to produce positive results.

The 1993 law restricting legal abortion has been a concern for many feminist and women's health advocates since before its inception and has continued to be denounced by a variety of sources ever since. Hand-in-hand with the abortion debate are the issues of access to contraceptives and the re-institution of sex education in public schools. As the most controversial of these debates, abortion has always taken front stage. Summarizing the 2001 Polish Tribunal on Abortion, scholars Girard and Nowicka warned that the current law had produced only 
negative consequences for Polish women and families and, in fact, had put Poland in violation of international human rights standards:

Poland is a party to the major international human rights treaties, such as the International Covenant on Civil and Political Rights and the Convention on the Elimination of All Forms of Discrimination Against Women. Together these treaties guarantee (to human beings or persons, including women) the right to life, liberty and security of the person, privacy, the highest attainable standard of health, and access to healthcare services without discrimination on the basis of sex. As stipulated by the Universal Declaration of Human Rights, a human being or person must be born. ${ }^{111}$

It is this legal violation of international treaties and covenants which exemplifies Poland's willingness to disregard human rights when it sees fit. Consequently, feminists are able to use this contradiction between the Polish government's legal commitments and their actions in the form of national legislation to undermine the government's legitimacy in human rights issues. Not only feminist groups, but medical organizations, healthcare advocates, sociologists and even the United Nations Committee on Human rights have commented on the detrimental effects of Poland's restrictive abortion policies and have encouraged liberalization of the law and decriminalization of the procedure. At present most activists and analysts have estimated that the dispute over abortion will continue for some time. In a recent newspaper article, feminist scholar Agnieszka Graff realistically stated that "Given the enormous political influence of the Catholic Church, legislation of abortion is likely to remain a fantasy for decades. The new strategy is to downplay topics which divide women (abortion and sexual minority rights)," which may never find consensus amongst women's activists and alienate supporters from one another. ${ }^{112}$

And so, women's organizations in Poland including most notably the annual Women's Congress has managed to gain publicity and political success with its recent strategies and

\footnotetext{
${ }^{111}$ Girard and Nowicka, 27.

112 Agnieszka Graff, "Polish feminism is no longer ridiculed," in The Guardian (Online Edition, 9 April 2011), http://www.guardian.co.uk/commentisfree/2011/apr/09/polish-feminism-gender-equality . Access date: 15 June 2011.
} 
causes. The recent parity law ensuring a 35 percent quota of women on electoral lists and another bill pertaining to childcare for young children are considered major victories for Polish women's organizations. ${ }^{113}$ These bills are uncontroversial in nature as Graff described, and have found success in all probability due to their non-divisive goals as well as based upon their merits as legislation.

Aside from the promotion of new legislation the Women's Congress, as well as nearly all feminist and women's organizations, has been encouraging women to enter into more positions of responsibility, leadership and power, including political positions. Of course, the difficulty in moving into such positions takes time, but who has the backing and encouragement of the Women's Congress though with a discerning lens. Women's issues organizations and feminist activists have long believed that progress will be made towards achieving gender equality as women move into positions of power in business and government. While neither of these moves has seen great leaps in progress, placing women in positions of political power is a change which may take years to implement in Central and Eastern Europe.

Just as every other country in the postcommunist region, Poland saw a dramatic drop in women's political participation as well as in their involvement in parliamentary level national politics during the first post-communist decade. ${ }^{114}$ This decline in women's political participation has been explained by a multitude of theories ranging from women's perceived "passive attitudes," their distaste for politics, to the intentional exclusion of women from political life. ${ }^{115}$ While the majority of such theories are based in public perceptions and not reliable studies they are generally accepted and propagated into collective memory which

\footnotetext{
113 Ibid.

${ }_{114}$ Malgorzata Fuszara, "Feminism, the New Millenium, and Ourselves: A Polish View," Signs 25 (2000): 1070.

115 Fuszara, "Feminism," 1070.
} 
perpetuates the cycle of women's exclusion and derision. Barbara Einhorn offered an alternate explanation for women's decreasing political participation after 1989:

Another reason for the dearth of female politicians appears to lie in a rejection of politics and the public sphere as a 'dirty' business best left to men. Perhaps most significant as a cause is the current, apparently ubiquitous view in East Central Europe that women's issues constitute a second rank or even superfluous political agenda. This is partly the legacy of state socialism's designation of the 'woman question' as a separate and discrete set of issues, rather than as something integral to, both affected by and in turn directly impinging on, all social and economic policy decisions. ${ }^{116}$

Recently, the tide seems to be changing and as mentioned, in December of 2010 the Sejm passed a new parity law requiring a minimum of $35 \%$ men and $35 \%$ women on each election list for Polish government and European parliament elections. ${ }^{117}$ Most interestingly, Polish Prime Minister Donald Tusk, a self-proclaimed "avowed advocate of parity" claimed that were it up to him, he would assure a $50 \%$ parity law in Poland. ${ }^{118}$ It is also important to note the obvious fact that parity laws make no guarantee as to the type of female candidate on the election lists. There are many female politicians and candidates in Poland who do consider themselves Catholic, conservative and most certainly not feminist. With this concern, scholar Monika Platek warns of supporting women in politics simply for the sake of promoting women:

Not only do we have the right to aim at a larger quota of women in all kinds of institutions but also to check out the ones we vote for...Although it is important at this stage to have more women in politics, if we have a choice it is better to choose those who for the benefit of both women and men care for women's issues than those who care merely for their own private interests, and - not wanting to become conspicuous - work diligently to maintain the patriarchal tradition. 119

Aside from politics, the workplace and labor force are also places where feminists have noted serious issues of gender inequality. Transitional processes from communist to democratic, capitalist systems have been studied and their effects have been deemed particularly challenging

\footnotetext{
${ }^{116}$ Einhorn, 157.

${ }^{117}$ Gazeta Wyborcza, "Sejm uchwalił. Kobiety się liczą na listach," 4 December 2010, http://wyborcza.pl/1,75478,8765321,Sejm_uchwalil_Kobiety_sie_licza_na_listach.html.

${ }^{118}$ Gazeta Wyborcza, ibid.

${ }^{119}$ Monika Platek, “Hostages of Destiny: Gender Issues in Today’s Poland," Feminist Review 76 (2004), 19.
} 
for women in an economic sense. Scholars have claimed, "The effects of privatization and related economic and social policies have hit women hard... Women especially have been hurt by the elimination of state-supported child care, curtailment of maternity leaves, the loss of the right to abortion and the re-emergence of the ideology of domesticity." ${ }^{120}$ Noting wage discrepancies, pension earnings, retirement ages, maternity leave, and unfair firings, women have been striving to improve their situation in the workplace for decades. In addition to the previously mentioned unemployment statistics, women's pay is comparatively less than men's: according to the Global Gender Gap report from 2010, Polish women can expect an annual salary equivalent to $\$ 11,957$ USD, significantly less than their male counterparts who average the equivalent of $\$ 20,292$ USD. ${ }^{121}$ Furthermore, based upon a survey measuring women's ability to rise to positions of enterprise leadership, Poland received a median score indicating moderate difficulty for women to rise in the workplace hierarchy in pace with their male colleagues. ${ }^{122}$

From the workplace into society, Polish feminists have noticed the serious issues of pornography, prostitution, widespread misogynistic attitudes and violence against women require attention. Though the realm of violence against women is an area where much of the developed world has made progress there are still disturbing statistics to report. "Even a seemingly low domestic abuse incident rate of 3 percent in Poland translates into 1,465 women being abused each day." ${ }^{\prime 23}$ When the statistics are elaborated upon, it becomes easy to understand how something as small as 3 percent could seem so unimaginably high.

\footnotetext{
${ }^{120}$ Bystydzienski, 507.

${ }^{121}$ Ricardo Hausman, Laura D. Tyson, and Saadia Zahidi, “The Global Gender Gap Report,” World Economic Forum 2010, 252.

122 Ibid, 252.

123 “World Development Report 2012: Gender and Development." The International World Bank for Reconstruction and Development / The World Bank (2011), 367.
} 
Polish author Eva Stachniak immigrated to Canada from Poland in 1981 and returned twelve years later, noticing things about her home that she had never considered before. Remarking on the pornographic photographs of women and a rosary both decorating her taxi cab, Stachniak's perspective as a Polish woman and a feminist quickly acknowledged the stark contradiction in these two items' cultural significance. What place did the objectification and exploitation of women's sexuality have next to the ultimate religious symbol of purity and motherhood? Combining this type of individual experience with historic and cultural knowledge, Stachniak conveys an intimate and personal understanding of Polish women's societal status by focusing on the everyday instances of gender inequality and misogynistic attitudes that permeate Polish society. She said,

I see things I paid no attention to when I lived here. I see that women are publically patronized and stereotyped in everyday language...I am puzzled because the overwhelming majority of well-educated, professional women, women who in North America would at least consider the feminist premises, tell me that there is no need for feminism in Poland, that Polish women have a very special place in Polish society. ${ }^{124}$

Individual women's perspectives on their lives in Poland are an invaluable resource in achieving a more thorough and realistic understanding of how Polish women view their society and its current women's issues. In an interview in 2010, Joanna Mucha, a member of the Sejm (lower house of Polish parliament) described her views on feminism and her experiences as a female politician with equal measures enthusiasm and aloofness. When asked if she selfidentified as a feminist, Dr. Mucha (who holds a Ph.D. in economics) responded, "The answer is difficult because of abortion, my children and career. I am not a stereotypical feminist. The stereotype is heavy and wrong. Personally, I do identify as my own feminist.”

${ }^{124}$ Eva Stachniak, “Why Did We Not Become Feminists? Women in Poland.” NWSA Journal 7 (1995): 69. 
With this response, Dr. Mucha recognizes, and to an extent, accepts a generally negative stereotype of feminists. By qualifying that she rejects this negative, "heavy and wrong" aspect of feminism, but still identifying as her "own feminist," she has simultaneously embraced a traditional view without totally disregarding the concept of the movement and what it stands for. This combination is particularly interesting when it is noted that Dr. Mucha holds many conservative views on social issues and is opposed to abortion, same-sex marriage and civil unions, euthanasia and in-vitro fertilization. When asked how important it is for the public to see strong women as figures in politics and power positions Dr. Mucha goes on to express some very feminist views, stating that "It is very important. There is not really a strong representation of women [yet]." Concluding, Dr. Mucha described her hopes for future generations of Polish women saying, "I have very easy dreams. Women should have possibilities to make a career or stay at home - also for men to stay at home. Gender equality. Freedom of choice. Equal opportunities in your lifetime and career." 125

Polish scholar Aneta Gawkowska is more openly critical of the feminist perspective, if only from an academic perspective. She contends that "the greatest contributions from Polish feminism are merely imitation" and that "Polish feminists are not in touch with global feminism. They are imitating rather than responding with something of their own.” Dr. Gawkowska also believes that "all stages of feminism were adopted simultaneously in Poland. There were no waves as there were, in, say the United States." This bold statement (rather common, even amongst Polish scholars) emphasizes that the historical memory and significance of Polish women's political action and discourse in the early twentieth century can truly be considered a period of forgotten history. Finally, Dr. Gawkowska is keen to discuss the "new feminist" movement which can be described as a conservative, Catholic women's movement which has re-

\footnotetext{
${ }^{125}$ Abigail Miller, “Interview with Dr. Joanna Mucha,” Warsaw, Poland. 2 December 2010.
} 
appropriated the term 'feminism' for its own purposes. New feminism embraces women's roles as wives and mothers, glorifying the image of the Matka Polka and promoting 'equality through difference' which harks back to the segregationist calls for 'separate but equal' rights during the American civil rights era. ${ }^{126}$

Speaking with scholar Dr. Nina Gładziuk exemplified the frustrated, yet optimistic perspective of Polish academic feminists. Like Dr. Gawkowska, Dr. Gładziuk does not recognize early twentieth century history of feminist activity as significant to the women's movement today. She stated, "if there was a historical basis for feminists, it would be easier (a more successful movement)," and that "women's suffrage is taken for granted - there was no necessity to organize. Later, socialism had basically (guaranteed) equality of the sexes and women didn't have to fight for anything." This is a common view in Polish society and is a valid interpretation of the historical record and memory (or lack thereof). Dr. Gładziuk also makes particular note of the unique combination of forces which have influenced Polish feminism including nationalism, the Catholic Church and the lack of consensus amongst women activists. In conclusion, Dr. Gładziuk recognized that "there are all kinds of barriers to feminism in Poland: cultural, linguistic, religious, political, etc." but seemed optimistic that with new efforts, increased scholarship and continued work there might be progress in gender equality in Poland. ${ }^{127}$

Considering this varied sample of women's perspectives on Polish feminism and present situation in national politics, it is wise to remark that historical and cultural ideals about women in Poland have always been strong in the minds of the public and problematic for women. Hanna Jankowska described the cultural imprint of Polish women, cultivated over the past two centuries, saying, "a model of victimized, self-sacrificing woman has developed, a woman fully

\footnotetext{
${ }^{126}$ Abigail Miller, "Interview with Dr. Aneta Gawkowska," Warsaw, Poland. 6 December 2010.

127 Abigal Miller, “Interview with Dr. Nina Gładziuk,” Warsaw, Poland. 13 December 2010.
} 
devoted to her family (or homeland) who doesn't know her own happiness or pleasure, indeed who was taught that she has no right to be happy as an independent individual.",128

Knowing that cultural impressions and norms have a great impact on behavior cannot be surprising. The true extent of such influences is more difficult to estimate; however, it is not unreasonable to conclude that in some way (by agreement or rejection) most women in Poland and around the world are affected by their respective national and cultural stereotypes of what it means to be a woman. Many articles addressing women's issues in Poland make note of the traditional characteristics of women; often in her work, feminist scholar Anna Titkow references the idea of "the model of the heroic Polish woman coping with all sorts of burdens," comprising a "“social genotype' of a woman coping discreetly with very difficult demands, in accordance with the spirit of self-sacrifice for the homeland and family, not expecting anything other than acknowledgment in return."

In addition to the long-established vision of the suffering mother-Pole and cultural tradition, Polish feminism has been hindered by continued anti-feminist sentiment and 'new feminist' organizations which are actually conservative, Catholic women's groups. These 'new feminist' organizations are in reality, not organizations which share values with Polish or Western feminist movements. 'New feminism' believes in equality of the sexes by highlighting the different physical features and life purposes between men and women with the simultaneous goal of undermining traditional feminism. ${ }^{130}$ Feminist movements in Poland will have to compete with these historic, cultural prejudices and anti-feminist groups by maintaining their advocacy and continuing to strive for potential benefit to society.

\footnotetext{
128 Jankowska, ibid, 175.

${ }^{129}$ Anna Titkow, "Political Change in Poland: Cause, Modifier, or Barrier to Gender Equality?," in Gender Politics and Post-Communism, 253.

${ }^{130}$ Abigail Miller, "Interview with Aneta Gawkowska" and Bystydzienski, 507.
} 
If there is one thing that Polish feminism has in abundance, it is potential. The Global Gender Gap Report of 2010 is an annual study which "examines the gap between men and women in four fundamental categories: economic participation and opportunity, educational attainment, health and survival and political empowerment." ${ }^{131}$ The top ranking signifies a state very near to closing the gender gap between men and women; the bottom ranking signifies a state where the gap between men and women is wide open, indicating a tremendous amount of inequality. In 2010, Poland ranked forty-third out of the one hundred and thirty-four countries tracked, moving up seven places in the rankings from the previous year. ${ }^{132}$ Furthermore, the report ranks Poland forty-first in women's political empowerment and sixty-third in women's economic participation and opportunity. ${ }^{133}$

The World Development Report 2012 on Gender Equality and Development paints a much more intimate and personal portrait of women's experiences in Poland while quantifying their lives in significant statistics. The report identifies women's double burden as workers and caregivers as a significant obstacle to gender equality stating that in combined (men's and women's) effort spent by families, women devote 36 percent of time on market activities and 67 percent on housework and care, presumably leaving their male partners to spend 64 and 33 percents on those duties, respectively. ${ }^{134}$

While these statistics represent both positive accomplishments for the Polish state (as well as its feminist movement and women's organizations who have worked tirelessly to further gender equality in their nation) they also represent areas which would be improved with significant attention and effective policymaking. Politicians within Poland as well as

\footnotetext{
${ }^{131}$ Global Gender Gap Report, 4.

132 Ibid, 8.

${ }^{133}$ Ibid, 252.

134، World Development Report 2012,” ibid, 243.
} 
intergovernmental organizations such as the European Union (of which Poland is a member) recognize the benefits of performing well in these types of rankings, not only politically but economically as well. The report's authors purport, "The index continues to track the strong correlation between a country's gender gap and its national competitiveness... Over time therefore, a nation's competitiveness depends significantly on whether and how it educates and utilizes its female talent."135

This female talent has branched out and is now working in many and every way to benefit the Polish state, men, women and children in society. Feminists such as Agnieszka Graff contribute with their writing talents and inspire the public to discuss and debate women's issues. Other writers such as Manuela Gretkowska take their passions and begin a women's political party (Partia Kobiet) to challenge the status quo in national elections. ${ }^{136}$ Gretkowska's party was unique in that its entire political platform was structured around women's issues and inclusion in the democratic process. Gretkowska felt it was necessary to found such a party to facilitate more women's entrance into the political world and to help prevent further restrictions to the already severe abortion law. ${ }^{137}$

Each year more women turn out for demonstrations and to attend political talks, more sign petitions and talk with their friends and family about women's lives in Poland or why women's issues are of consequence to society. The potential to grow and develop and define within Polish society awaits each member and organization of women and feminists as they continue to advocate for gender equality and improvements to society.

\footnotetext{
135 Ibid, 32.

${ }^{136}$ Małgorzata Fidelis, Women, Communism, and Industrialization in Postwar Poland (New York: Cambridge University Press, 2010), 254.

${ }^{137}$ Danuta Filipowicz, "Feminist parties: Everything for the future and nothing to hide," The Krakow Post (Online Edition: 5 October 2007) http://www.krakowpost.com/article/577. Access date 15 June 2011.
} 


\section{Conclusions: The Unique Case of Polish Women}

Women in Poland have a long way to go in promoting feminist principles and achieving gender equality. Political and economic transitions in the region and in Poland specifically since 1989 have been tremendously influential in determining women's place in society, government, and the labor force. "Poland, in particular, provide[s] us with a timely reminder that the promotion of women's rights and citizenship is not necessarily a story of linear progress and consolidation." ${ }^{" 138}$ While progress is slow at times, the future of Polish society will depend upon the inevitable promotion and acceptance of a truly fair and equal situation for both men and women.

Scholar Ruth Lister suggested that "if the concept of women's citizenship is to be at all useful for women, it is best understood as a process which women stake their claim to be included in the construction of civil society and democracy. But this process inevitably involves women's agency and struggle. Poland sharply illustrates that without a responsive and responsible state, women's organizations cannot be effective, and women's citizenship is fairly empty of meaning.",139

Perhaps this type of bold and decisive statement will inspire men and women together to enact change and continue the positive turn towards political and social equality which institutions like the Sejm, women's organizations and feminist groups have already undertaken.

Undoubtedly there will need to be considerable, continued influence from the international community and international organizations which will instigate and encourage development and change in Poland. The World Development Report on Gender Equality and Development also notes that international organizations and development can be crucial to improving the quality of women's lives:

International NGOs and networks of women's groups can be allies in spurring and monitoring reform. Working locally, regionally, and nationally, with a strong field presence and deep knowledge of local conditions, these organizations can assist governments in assessing gender-

\footnotetext{
${ }^{138}$ Coyle, 59.

${ }^{139}$ Ibid, 64.
} 
differentiated impacts of various policy responses and lobby for policy change in priority areas. $^{140}$

The historical context of feminism has created complex issues in the development of modern Polish women's movements. Feminism, in particular, has been received warmly by women who recognized stark gender inequality and were eager to work towards overcoming it. On the other hand, feminism has been vilified and rejected by groups in society who either deny issues of gender inequality or view feminist principles as contributing to the problem as a divisive force. Feminism has never had one meaning in Poland and it has been manipulated to represent the interests or disdain of the left and right political sides. The lack of consensus on feminism's meaning also extends to how women in Poland cannot come to an accord on how to approach women's issues. The wide variety of responses to promoting and resolving women's issues has created a breadth of women's organizations which range from 'new feminist' to moderate to radical feminist and everywhere along the continuum.

Women in Poland have gone back and forth in their positions, split into factions and still remain divided today as a part of the historical legacy of Solidarity and the effect of democratic and economic transitions. The restrictive abortion law remains in place; feminism is still a dirty word; a parity law is required to ensure women can find a place on election lists. Like most countries, Poland is a place where women have room to improve their lives on economic, social and political terms; feminism and attention to so-called women's issues will benefit not only Poland's women, but all of its citizens.

Just as with cancerous cells, ingrained behavior which harms citizens must be excised from the population's mentality. The work that Polish feminists and their allies are doing will improve the quality of life and enhance the country's commitment to social justice. As the old

140 “World Development Report 2012,” ibid, 349. 
saying goes, the personal is political. Gender equality is important because a well-functioning society is important. Citizens are important. People are important. "Persistent differences in power and status between men and women can become internalized in aspirations, behaviors, and preferences that perpetuate the inequalities... Only by attempting to equalize outcomes can one break the vicious cycle of low aspirations and low opportunity." ${ }^{, 141}$ No person, no citizen should be suffered to such bleak prospects for their life; the movement for gender equality can and will heighten aspirations and improve opportunity in Poland and around the world.

141 “World Development Report 2012,” ibid, 4. 


\section{Bibliography}

\section{Primary}

“Amazonki XX wieku.” Kurjer Warszawski 76 (16 March 1912), 3-4.

Filipowicz, Danuta. "Feminist parties: Everything for the future - and nothing to hide." The Krakow Post (Online Edition, 5 October 2007), Access date: 15 June 2011. http://www.krakowpost.com/article/577.

Graff, Agnieszka. "Polish feminism is no longer ridiculed." The Guardian (Online Edition: 9 April 2011) Access date: 15 June 2011. http://www.guardian.co.uk/commentisfree/2011/apr/09/polis-feminism-gender-equality.

Hausmann, Ricardo, Tyson, Laura D, and Zahidi, Saadia. “The Global Gender Gap Report 2010.” World Economic Forum, 2010.

“Kobieta w rodzinie ziemiańskiej.” Rzepniewska, 40-42.

Korolczuk, Elizabeth. “Warsaw Manifa 2011.” http://www.manifa.org. 15 April 2011.

Miller, Abigail. “Interview with Dr. Aneta Gawkowska.” Warsaw, Poland. 6 December 2010.

Miller, Abigail. “Interview with Dr. Joanna Mucha.” Warsaw, Poland. 2 December 2010.

Miller, Abigail. "Interview with Dr. Nina Gładziuk.” Warsaw, Poland. 13 December 2010.

“Sejm uchwalił. Kobiety się liczą na listach.” Gazeta Wyborcza. 4 December 2010.

http://wyborcza.pl/1,75478,8765321,Sejm_uchwalil_Kobiety_sie_licza_na_listach.html.

"World Development Report 2012: Gender Equality and Development." The International Bank for Reconstruction and Development / The World Bank, 2011.

\section{Secondary}

Blobaum, Robert. “The 'Woman Question' in Russian Poland, 1900-1914.” Journal of Social History 35 (2002): 799-824.

Blobaum, Robert and Donata Blobaum. "A Different Kind of Home Front: War, Gender and Propaganda in Warsaw, 1914-1918," in Propaganda and the First World War, editor Troy Paddock (forthcoming with Brill, 2012).

Bystydzienski, Jill M. “The Feminist Movement in Poland: Why So Slow?” Women's Studies International Forum 24 (2001): 501-511. 
Cole, Maria. "Gender and Power: Sex Segregation in American and Polish Higher Education as a Case Study.” Sociological Forum 12 (1997): 205-232.

Coyle, Angela. 'Fragmented Feminisms: Women's Organisations and Citizenship in 'Transition' Poland." Gender and Development 11 (2003): 57-65.

Einhorn, Barbara. Cinderella Goes to Market: Citizenship, Gender, and Women's Movements in East Central Europe. New York, Verso Publishing, 1993.

Fidelis, Małgorzata. "Poland." In The Oxford Encyclopedia of Women in World History. Oxford: Oxford University Press, 2008.

Fidelis, Małgorzata. Women, Communism, and Industrialization in Postwar Poland. New York: Cambridge University Press, 2010.

Funk, Nanette and Mueller, Magda, eds. Gender Politics and Post-Communism: Reflections from Eastern Europe and the Former Soviet Union. New York: Routledge, 1993.

Fuszara, Małgorzata. "Abortion and the Formation of the Public Sphere in Poland," in Gender Politics and Post-Communism: Reflections from Eastern Europe and the Former Soviet Union, edited by Nanette Funk and Magda Mueller, 241-252. New York: Routledge, 1993.

Fuszara, Małgorzata. "Legal Regulation of Abortion in Poland.” Signs 17 (1991): 117-128.

Fuszara, Małgorzata. "Feminism, the New Millennium, and Ourselves: A Polish View." Signs (2000): 1069-1075.

Ghodsee, Kristen. "Feminism-by-Design: Emerging Capitalisms, Cultural Feminism, and Women's Nongovernmental Organizations in Postsocialist Eastern Europe.” Signs 29 (2004): 727-753.

Girard, Françoise and Nowicka, Wanda. "Clear and Compelling Evidence: The Polish Tribunal on Abortion Rights." Reproductive Health Matters 10 (2002): 22-30.

Gomick, Janet C., Rachel A. Rosenfeld, and Heike Trappe. "Gender and Work in Germany: Before and After Reunification.” Annual Review of Sociology 30 (2004): 103-124.

Gontarczyk-Wesola, Ewa. "Women's Situation in the Process of Change in Poland." In Ana's Land: Sisterhood in Eastern Europe, edited by Tanya Renne, 34-41. Boulder: Westview Press, 1997.

Harsch, Donna. Revenge of the Domestic: Women, The Family, and Communism in The German Democratic Republic. Princeton: Princeton University Press, 2007. 
Hauser, Ewa, Barbara Heyns and Jane Mansbridge. "Feminism in the Interstices of Politics and Culture: Poland in Transition.” In Gender Politics and Post-Communism, edited by Nanette Funk and Magda Mueller, 257-273. New York: Routledge, 1993.

Hauser, Ewa. "Traditions of Patriotism, Questions of Gender: The Case of Poland." In PostCommunism and the Body Politic, edited by Ellen E. Berry, \#-\#. New York: New York University Press, 1995.

Jancar, Barbara. "Women in the Opposition in Poland and Czechoslovakia in the 1970's." In Women, State, and the Party in Eastern Europe, edited by Sharon Wolchik and Alfred Meyer, 169-170. Durham: Duke University Press, 1985.

Jankowska, Hanna. “Abortion, Church and Politics in Poland,” Feminist Review 39 (1991): 174-181.

Kellogg, Charlotte. "Poland's Women.” The North Atlantic Review 212 (1920): 510-523.

Kenney, Padraic. "The Gender of Resistance in Communist Poland," The American Historical Review 104 (1999): 399-425.

Kulczycki, Andrzej. "Abortion Policy in Postcommunist Europe: The Conflict in Poland." Population and Development Rule 21 (1995): 471-505.

Lederer, Gerda and Robert Schönsee. "The Gentle Revolution.” Political Psychology 12 (1991): 309-330.

Leven, Bozena. “Unemployment Among Polish Women.” Comparative Economic Studies 35 (1993): 135-145.

Łobodzińska, Barbara. Family, Women and Employment in Central-Eastern Europe. Westport: Praeger, 1995.

Mishtal, Joanna Z. "Matters of 'Conscience': The Politics of Reproductive Healthcare in Poland." Medical Anthropology Quarterly 23 (2009): 161-183.

Nowakowska, Urszula. "The New Right and Fundamentalism.” In Ana's Land: Sisterhood in Eastern Europe, edited by Tanya Renne, 26-33. Boulder: Westview Press, 1997.

Nowicka, Wanda. "Ban on Abortion in Poland. Why?" In Ana's Land: Sisterhood in Eastern Europe, edited by Tanya Renne, 42-46. Boulder: Westview Press, 1997.

Okolski, Marek. “Abortion and Contraception in Poland." Studies in Family Planning 14 (1983): 263-274. 
Olsen, Frances Elizabeth. "Feminism in Central and Eastern Europe: Risks and Possibilities of American Engagement.” The Yale Law Journal (1997): 2215-2257.

Penn, Shana. Solidarity's Secret: The Women Who Defeated Communism in Poland. Ann Arbor: University of Michigan Press, 2005.

Platek, Monika. "Hostages of Destiny: Gender Issues in Today’s Poland." Feminist Review 76 (2004): 5-25.

Ponichtera, Robert M. "Feminists, Nationalists, and Soldiers: Women in the Fight for Polish Independence.” The International History Review 19 (1997): 16-31.

Reading, Anna. Polish Women, Solidarity and Feminism. New York: Palgrave Macmillian, 1992.

Tempska, Urszula. "Double Marginality Or/As Double Indemnity?: "Europe" In The Prose of Polish Women.” symplokē 5 (1997): 183-205.

Titkow, Anna. "Political Change in Poland: Cause, Modifier, or Barrier to Gender Equality?" In Gender Politics and Post-Communism: Reflections from Eastern Europe and the Former Soviet Union, edited by Nanette Funk and Magda Mueller, 253-256. New York: Routledge, 1993.

Summerfield, Penny. "Gender and War in the Twentieth Century." The International History Review 19 (1997): 2-15.

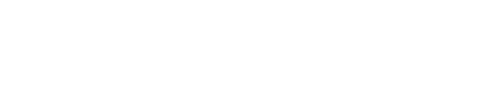

